\title{
Inhibitory protection of steels from high-temperature corrosion in acid solutions. A review. Part 1
}

\author{
Ya.G. Avdeev* and Yu.I. Kuznetsov \\ A.N. Frumkin Institute of Physical Chemistry and Electrochemistry, Russian Academy of \\ Sciences, Leninsky pr. 31, 119071 Moscow, Russian Federation \\ *E-mail: avdeevavdeev@mail.ru
}

\begin{abstract}
This review discusses the most important fields of practical application of acid solutions. They are used in the oil and gas industry for acid stimulation of oil- and gas-bearing strata and at metallurgical plants for removal of high-temperature scale from the surface of steel products. It is noted that during operation these process fluids can be heated to temperatures $t \geq 100^{\circ} \mathrm{C}$, which significantly increases their corrosiveness toward steel technological structures or steel products with which they contact. Analysis of literature reviews on acid corrosion inhibitors of metals shows the absence of detailed information on the possibility of steel protection in acid solutions at $t \geq 100^{\circ} \mathrm{C}$. In view of this, the long-term experience in the field of inhibitory protection of steels against corrosion in acid solutions at elevated temperatures $t>80^{\circ} \mathrm{C}$ is summarized and a critical analysis of the results achieved in this area and existing theoretical concepts is performed. The technical specifics of studying the corrosion and electrochemical behavior of steels in acid solutions at elevated temperatures are considered. It is noted that the most correct data on steel corrosion under these conditions cannot be obtained without autoclave equipment. Data on the corrosion rates of steels of various grades in solutions of mineral and organic acids under high-temperature corrosion conditions are summarized and analyzed. The activation energies of corrosion of steels in acids are analyzed. Data on the electrochemical behavior of steels in acids at temperatures close to $100^{\circ} \mathrm{C}$ are presented. The corrosion rates of steels observed in acid solutions under high temperature corrosion conditions are extremely high, which makes it impossible to use them in these environments without special protective measures. Metals in contact with hot solutions of both mineral and organic acids need to be protected. It is noted that corrosion inhibitors are the only acceptable way to protect metals under these conditions. The bibliography includes 123 references.
\end{abstract}

Keywords: high-temperature acid corrosion, steel, corrosion inhibitors, acidizing, acid pickling of steels, hydrochloric acid, sulfuric acid, phosphoric acid, acetic acid, formic acid, citric acid.

Received: March 5, 2020. Published: March 31, 2020

doi: $\underline{10.17675 / 2305-6894-2020-9-2-2}$ 


\section{Introduction}

Solutions of non-oxidizing acids used for the acidic treatment of oil- and water-bearing strata, scale removal from metal surfaces, and cleaning of mineral deposits from the inside surfaces of pipelines and equipment are among the most corrosive industrial environments. In practice, the main method for the protection of metal structures in acid solutions involves the use of corrosion inhibitors (hereinafter, inhibitors), i.e., chemical compounds or formulations that, when present in sufficient concentrations in a system, decrease the corrosion rates of metals without changing significantly the concentration of any corrosive reagent [1]. The vast majority of acid corrosion inhibitors are efficient at temperatures up to $t=80^{\circ} \mathrm{C}$. In most cases, they are completely desorbed from the metal surface above this temperature, which significantly reduces their protective effect. Unfortunately, the vast majority of the known corrosion inhibitors do not meet the technical and environmental requirements of modern industries, where acid solutions in contact with a metal can be heated to $t \geq 100^{\circ} \mathrm{C}$. Moreover, inhibitors should not be hazardous to humans and to the environment.

Inhibitors capable of protecting metal structures of the oil- and gasfield equipment in contact with acid solutions at $t \geq 80^{\circ} \mathrm{C}$ (high-temperature acid inhibitors) need to be created for the oil and gas industry where acid treatment of hydrocarbon strata with elevated temperatures at the well bottom is required more and more often. The first patent on the stimulation of carbonate oil strata with hydrochloric acid was obtained by Herman Frasch from Standard Oil back in the late 19th century [2]. However, acid stimulation did not find wide use in oil production in the next 30 years. Then, several serendipitous events occurred in the early 1930s. The Dow Chemical Company developed an efficient corrosion inhibitor for mineral acids and was asked to provide it for the acid treatment being performed by Pure Oil Company in one of their wells in Michigan. The effect of the treatment on production was positive, if not spectacular, but it provided the impetus to perform further treatments. Some of these later treatments produced excellent results and news of the technique quickly spread, spawning a whole host of small companies eager to participate in this new business [3].

A number of studies were performed to develop modern acid formulations for the treatment of oil and gas-bearing strata with elevated temperatures [4-12]. Treatments where acid formulations can be heated to $150^{\circ} \mathrm{C}$ or more were considered. While hydrochloric acid was exclusively used for the acid stimulation of oil wells at the beginning of the 20th century, the use of its mixtures with hydrofluoric acid in some cases began by the 1940s $[13,14]$. To date, the range of acids used or recommended for the stimulation of oil wells in individual form or in the form of mixtures expanded significantly [15-26]. Both inorganic ( $\mathrm{HCl}, \mathrm{HF}$, less commonly $\mathrm{H}_{2} \mathrm{SO}_{4}, \mathrm{H}_{3} \mathrm{PO}_{4}$, sulfamic acid, etc.) and organic acids (acetic, formic, monochloroacetic, etc.) are used.

The development of efficient high-temperature inhibitors opens prospects for intensifying the metal etching and removal of mineral deposits by considerably increasing 
the temperatures of acid solutions used in these operations [27, 28]. The large-scale etching of low-carbon steels for the removal of high-temperature scale is most often performed using solutions of mineral acids, such as $\mathrm{HCl}$ and $\mathrm{H}_{2} \mathrm{SO}_{4}$ [29]. Inorganic $\left(\mathrm{HCl}, \mathrm{H}_{2} \mathrm{SO}_{4}\right.$, $\mathrm{H}_{3} \mathrm{PO}_{4}$, sulfamic, etc.) and organic (citric, adipic, etc.) acids and sometimes their mixtures are also used to wash-off mineral deposits from the inner surfaces of metal equipment. Let us make a reservation right away that nitric, hydrofluoric and some "exotic" acids can be used in some special cases of these operations. In particular, they are used for the acid etching of chromium-nickel steels [30]. The discussion of these issues is left beyond the scope of our review due to some specifics of the properties of these acids [31-33].

Analysis of scientific literature shows that complete generalization of the achievements in the field of inhibitory protection of metals in acid media at elevated temperatures and analysis of the existing fundamental approaches to the solution of this problem are unavailable today. Researchers dealing with studies on acid corrosion inhibitors of metals ignore this problem, despite its importance for the modern industry. This is largely because it is difficult to obtain satisfactory results on the inhibitory protection of metals in acid solutions with $t \geq 80^{\circ} \mathrm{C}$ and because it is laborious to conduct corrosion studies in these environments. This is confirmed by the fact that recently published reviews [34-50] dealing with various groups of acid inhibitors do not discuss their applicability in high temperature corrosion, despite the practical significance of this problem. The problem of steel protection under high-temperature acid corrosion conditions is also ignored in discussions on more general issues of inhibitory protection of metals in the oil and gas industry [51]. Unfortunately, three important reviews [52-54] dealing with the protection of metals in acid media provide reference data on inhibitors capable of slowing down the corrosion of steel in acids at $t>80^{\circ} \mathrm{C}$ without any analysis of these data. Important achievements in the inhibitory protection of steels in $\mathrm{HCl}$ solutions $\left(0-160^{\circ} \mathrm{C}\right)$ by triazole-based composite inhibitors were discussed in Refs. [55, 56] devoted to the most relevant studies in the field of inhibitory protection of metals that are currently in progress. A recent review [57] dealing with the use of new inhibitors in the oil and gas industry provides a brief overview of current advances in their use in $\mathrm{HCl}$ solutions under high temperature corrosion conditions. It is known that high-temperature acid corrosion inhibitors of steels include some acetylenic compounds, $\alpha, \beta$-unsaturated carbonyl compounds and azomethines, azole derivatives, and $\mathrm{N}$-containing six-membered organic compounds as components of mixed inhibitors. The features of steel protection by these compounds in acid media and the specifics of the mechanism of their action are reviewed in [58-61]. The inhibition of metal corrosion in phosphoric acid solutions, including that at elevated temperatures, is reviewed in [62]. In recent years, studies on the protection of steels in acid media at elevated temperatures allowed fundamentally new inhibitors for these media to be developed. Theoretical approaches to the creation of such inhibitors also expanded considerably. All this requires a detailed generalization of the currently available literature data, their understanding and in-depth analysis. The urgent need in these 
generalizations is confirmed by the publication of the work [63] where the achievements in the inhibitory protection of various steels under high-temperature carbon dioxide corrosion conditions are analyzed. The critical importance of these studies is emphasized, since rather an active development of high-temperature oil and gas fields has been occurring recently.

In view of this, it appears important to summarize the long-term experience in the field of inhibitory protection of steels against corrosion in acid solutions at elevated temperatures, $t>80^{\circ} \mathrm{C}$, and perform a critical analysis of the results achieved in this field along with the existing theoretical concepts. For a better understanding of the hazards of high-temperature acid corrosion of metals, it is necessary to summarize the disparate and extremely rare data on the corrosion rates of steels in acids in the absence of inhibitors.

\section{Specifics of the techniques for studying the high temperature acid corrosion of steels}

In studies on the high-temperature acid corrosion of steels, experimenters encounter technical difficulties primarily caused by the fact that all or some components of acid solutions pass into the gas state at $t>100^{\circ} \mathrm{C}$ under atmospheric pressure. Experiments of this kind require that autoclave equipment be used. The design of an autoclave and its auxiliary components should be such that their parts in contact with a hot acid in the liquid or gas phase are not degraded by the acid and do not release compounds that could slow down metal corrosion.

Moreover, the acid corrosion of steels at $t>100^{\circ} \mathrm{C}$ occurs at very high rates $\left(k>1 \mathrm{~kg} /\left(\mathrm{m}^{2} \cdot \mathrm{h}\right)\right)$, which leads to a fast consumption of the acid solution available in the limited autoclave space. A significant decrease in its concentration in the solution will not allow true steel corrosion rates to be obtained. A steel sample can significantly change in geometric shape or dissolve completely due to the rapid interaction with the acid it contacts. In view of this, after the acid reaches the working temperature, the sample in the autoclave should be brought into contact with the corrosive medium for a fixed time and then isolated from it. Under ordinary conditions, this is done by sinking a sample from air into an acid and extracting it from the acid into air. In a heated autoclave, the gas phase is saturated with the acid that can actively react with the metal. To protect steel from exposure to the corrosive environment when the autoclave is heated and cooled, its design should include a device that puts the metal samples into a layer of transformer oil to insulate them for this period of time.

Heating of an autoclave involves an increase in pressure $(p)$ inside it due to the transition of the acid solution components to the gaseous state. An even greater contribution to this process is made by the reaction of the metal with the acid due to hydrogen evolution. The autoclave design should reliably withstand the effects of such pressures and allow safe pressure release from the autoclave after cooling. In some autoclave designs, oil hydraulic presses were provided to create an excess pressure artificially. 
The literature available to us contains practically no information on a technique for studying the corrosion of steels in acids at $t>100^{\circ} \mathrm{C}$ and design features of the laboratory set-ups that were used to perform the studies. One of the first set-ups was developed in the early 1960s by S.A. Balezin, N.I. Podobaev and F.K. Kurbanov (Figure 1) [64]. It was designed as an autoclave with a manual hydraulic press. Transformer oil was used as the working fluid for creating the required pressure. Steel samples were mounted on a fluoroplastic support in the lower part of a glass beaker that was filled with transformer oil. Then the required amount of an acid was poured into it; the vessel was closed with an oilresistant rubber cap and turned over. Thus, the samples were in oil in their initial position. In this position (cap down), the beaker with the samples was kept in the autoclave until the required $t$ and $p$ were reached. When the autoclave was turned by $180^{\circ} \mathrm{C}$ (time of reaction start), the samples got immersed into the acid. Returning the autoclave to its original position terminated the reaction. After cooling the autoclave to $t<100^{\circ} \mathrm{C}$, the excess pressure was released using a hand press and a plug. The characteristics of the autoclave were as follows: working capacity $0.45 \mathrm{~L}, t$ range up to $160^{\circ} \mathrm{C}, t$ maintaining accuracy $\pm 2^{\circ} \mathrm{C}, p$ range up to $500 \mathrm{~atm}, p$ maintaining accuracy $\pm 5 \mathrm{~atm}$. The authors showed experimentally that with this autoclave design, oiling of the samples with transformer oil slightly reduces the corrosion rate of the metal but does not introduce fundamental errors in the measurement results.

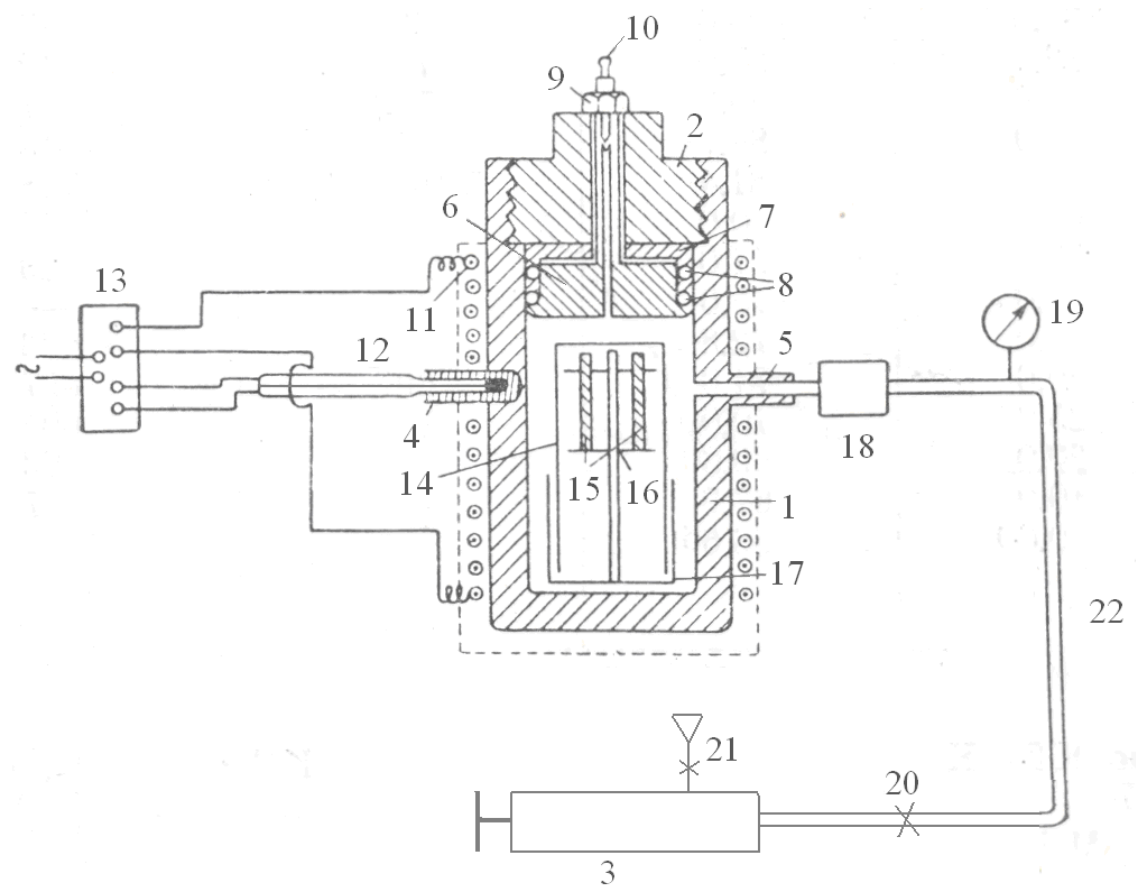

Figure 1. Scheme of the autoclave [64]: 1 - autoclave body, 2 - plug, 3 - manual hydraulic press, 4, 5-axle for turning the autoclave, 6, 7 - rod with metal gasket, 8 - fluoroplastic O-rings, 9 - pressure nut, 10 - exhaust plug for gases, 11 - electric spiral in porcelain rings, 12,13 - contact thermometer with electronic relay, 14, 15, 16 - beaker with samples and stand, 17 - rubber cap, 18 - oil seal, 19 - pressure gauge, 20 - high pressure valve, 21 funnel with a valve for filling the press with oil, 22 - oil pipe. 
A more advanced set-up was developed at the Grozny Research Institute (city of Grozny) (Figure 2) [65]. The specifics of the autoclave design was that it not only allowed the samples to be immersed and raised when the pressure was high in the autoclave, but also allowed rotation of the shaft where the samples were mounted. To speed up the autoclave cooling, its design included a water cooling system put around an electric furnace. Like in the previous case, the metal samples were located in a cup filled with transformer oil before and after contacting an acid. To conduct electrochemical measurements (electrode potential of the metal, measurement of the system electrical conductivity, voltammetric measurements), two electric inputs of special design were mounted inside the autoclave. The characteristics of the autoclave were as follows: working capacity $1.5 \mathrm{~L}, t$ range $110-250^{\circ} \mathrm{C}, t$ maintaining accuracy $\pm 4^{\circ} \mathrm{C}, p$ range $100-$ $1000 \mathrm{~atm}, p$ maintaining accuracy $\pm 5 \mathrm{~atm}$. An important design feature of this autoclave is the ability to immerse and remove metal samples to/from the acid solution at a required $t$ for a short time (a few minutes). Taking into account the possibility of a rapid decrease in the acid concentration in the solution at extremely high reaction rates of steel with the acid, this design feature allows one to obtain the least underestimated metal corrosion rates that are most close to reality.

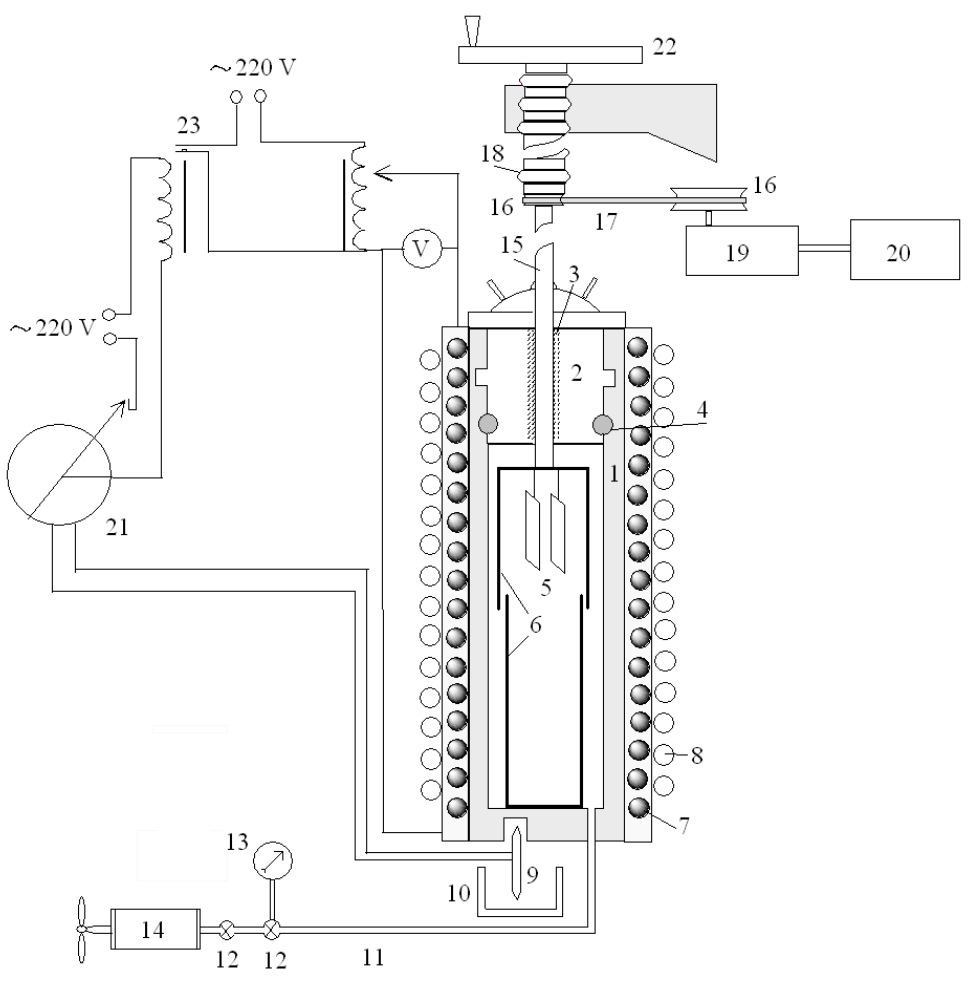

Figure 2. Scheme of the autoclave [65]: 1 - housing, 2 - cover, 3 -gland, 4 - fluoroplastic ring, 5 - steel samples, 6 - fluoroplastic beaker, 7 - heater, 8 - coil for cooling, 9 thermocouple to maintain the thermostat temperature at $50^{\circ} \mathrm{C}, 11$ - high pressure pipe, $12-$ valves, 13 - pressure gauge, 14 - oil press, 15 - shaft, 16 - pulleys, 17 - belt, 18 - worm shaft, 19 - gearbox, 20 - electric motor, 21 - PSR1-03 potentiometer, 22 - handwheel, 23 - relay. 
In a number of our works [66-69], the corrosion of various steels in $\mathrm{HCl}$ and $\mathrm{H}_{2} \mathrm{SO}_{4}$ solutions $\left(100-200^{\circ} \mathrm{C}\right)$ was studied in an automatic autoclave complex manufactured by Huber (Finland) (Figure 3). A significant drawback of these autoclaves compared to those described above -is that it is impossible to control its internal pressure, which can significantly increase due to hydrogen released upon metal dissolution. The design of the autoclaves was improved by quartz inserts in the form of cups into which an acid solution was placed. A facility was provided in the autoclave covers to suspend the metal samples on Teflon straps. The autoclave design does not allow one to directly metal samples place in an acid solution and withdraw them from it at a preset temperature. In view of this, corrosion tests were carried out by the following scheme. A specimen was placed into the autoclave quartz vessel containing an acid solution. The vessel was heated to a required temperature, kept for 40,70 or $130 \mathrm{~min}$ at that temperature, and cooled to $100^{\circ} \mathrm{C}$. The autoclave was then opened and the samples were withdrawn. In order to take the specimen mass loss during autoclave heating and cooling into account, the tests were duplicated with exposure for $10 \mathrm{~min}$ at the corresponding temperature. The corrosion rates over 30,60 , or 120 min periods were calculated from the difference between the specimen mass loss after 40-, 70-, or 130-minute exposures in the autoclave at the corresponding temperature and the mass loss after a 10-minute exposure. The autoclave characteristics were as follows: working capacity $-0.2 \mathrm{~L}, t$ range - up to $350^{\circ} \mathrm{C}$, accuracy of maintaining $t- \pm 3^{\circ} \mathrm{C}$ (when controlled manually), $p$ range - up to 170 atm. It should be understood that prolonged contact of a metal with an acid that occurs in these autoclaves can give significantly smaller-than-real steel corrosion rates, especially in those cases where the acid solution is quickly exhausted. In addition, the mass loss of metal samples during heating and cooling of acid solutions is not quite correctly taken into account.
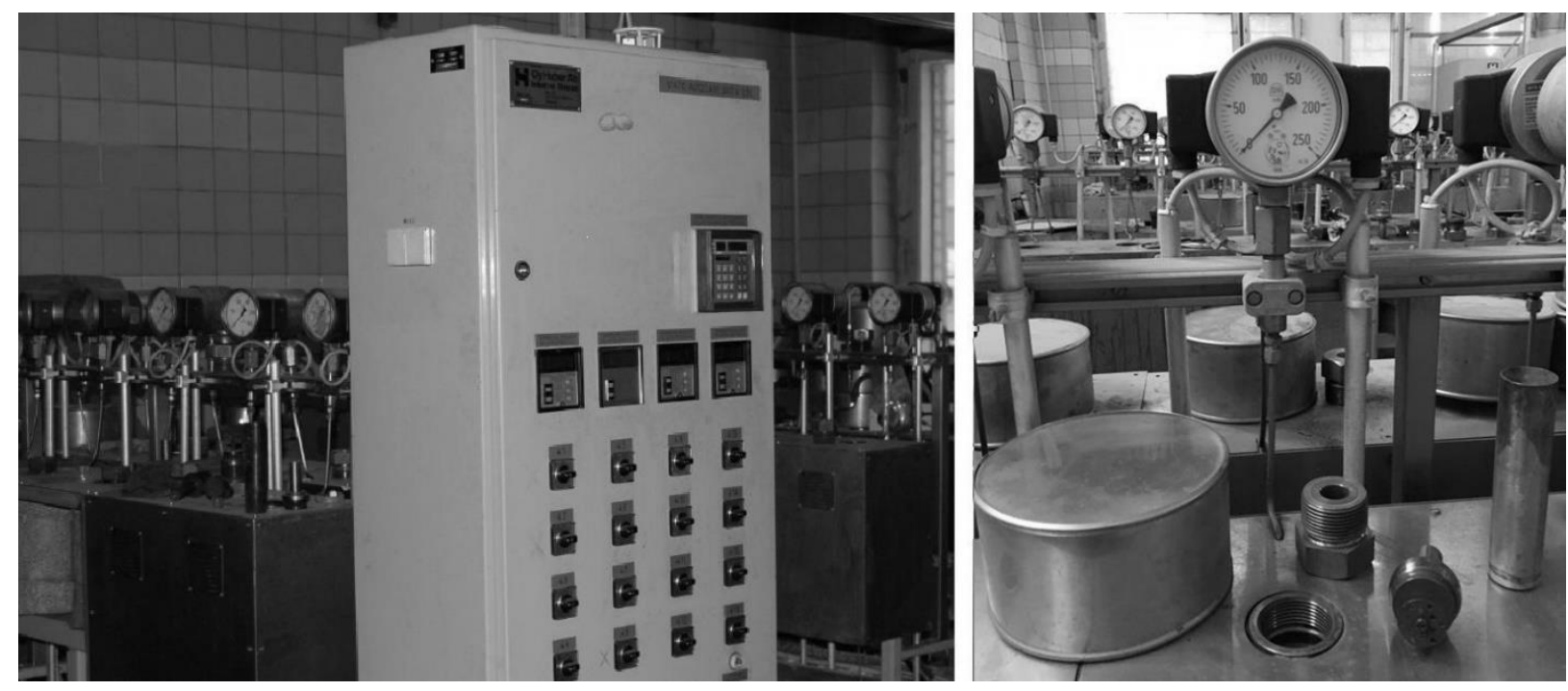

Figure 3. The autoclave room of A.N. Frumkin Institute of Physical Chemistry and Electrochemistry of the Russian Academy of Sciences. An autoclave stand is on the left, an autoclave is on the right. 
In cases where the process rate is very low under conditions of high-temperature acid corrosion of metals, the acid concentration changes slowly and the pressure due to hydrogen evolution does not increase considerably, studies can be made in stainless steel ampules lined with a fluoroplastic on the inside. Such devices were used to study the corrosion of chromium-nickel steels in $\mathrm{H}_{3} \mathrm{PO}_{4}$ solutions [70,71]. Ampules with samples placed inside $\left(S=5-25 \mathrm{~cm}^{2}\right)$ were filled with $\mathrm{H}_{3} \mathrm{PO}_{4}$ solutions $(V=25 \mathrm{ml})$, closed with a tightly screwed-on lid with a fluoroplastic gasket, placed in a heating cabinet and heated to the required $t(t$ up to $150^{\circ} \mathrm{C}, t$ maintaining accuracy $\pm 5^{\circ} \mathrm{C}$ ). Inside the oven, the ampules were rotated around a transverse axis at a rate of $80 \mathrm{rpm}$ by means of an electric motor, which allowed uniform mixing of the solution to be achieved. The duration of the corrosion tests was 6-58 hours, and the scatter of the results for 6 metal samples did not exceed $10 \%$.

Understanding the specific features of high-temperature acid corrosion mechanisms is impossible without performing a combination of electrochemical studies in such systems. Like corrosion tests, studies of this kind are complicated by the high corrosiveness of the environment toward the materials used to build the experimental set-up, including the steel working electrode, and the possibility of high pressures in the system or the need to maintain them. The simplest version of a set-up for studying the current-voltage characteristics of steel in acid solutions consists of glass or quartz electrochemical cells additionally equipped with a thermostatically controlled jacket [72]. Studies in such experimental set-ups is limited by the boiling point of the working medium, which is several degrees higher than the boiling point of water.

A special set-up consisting of an autoclave and an electrochemical cell inside it was developed at A.N. Frumkin Institute of Electrochemistry of the USSR Academy of Sciences [73]. It was intended for studying the kinetics of hydrogen evolution from aqueous solutions, including $\mathrm{HCl}$ and $\mathrm{H}_{2} \mathrm{SO}_{4}$ solutions, at $t>100^{\circ} \mathrm{C}$. The set-up characteristics were: $t$ range up to $300^{\circ} \mathrm{C}, p$ range up to $150 \mathrm{~atm}$. A technical feature of the set-up was that an inert metal served as the working electrode. This setup was used to study the kinetics of hydrogen evolution from aqueous solutions at elevated temperatures, which is important for a more detailed understanding of the process mechanism. The design features of the set-up do not allow one to use it for studying the electrode reactions of steel.

A special autoclave with a simpler design was used to study the electrochemical behavior of steel in $\mathrm{HCl}$ solutions at elevated temperatures (Figure 4) [74]. It was designed as a vessel from an inert material (length $120 \mathrm{~mm}$, diameter $38 \mathrm{~mm}$ ) with three platinum wires and one silver wire inserted into it through a special electric input. The upper platinum wire provided the contact of the working electrode (36G2S steel) mounted in a fluoroplastic stand, with a potentiostat, while the two lower ones served as the auxiliary electrodes. The silver wire electrolytically coated with silver chloride served as the reference electrode. The wires in the autoclave were isolated with porcelain rings. The acid covered only a fraction of the steel sample that served as the working surface. Transformer oil that insulated the upper platinum wire was above the $\mathrm{HCl}$ solution. Set-up characteristics: $t$ up to $120^{\circ} \mathrm{C}, p$ up to $300 \mathrm{~atm}$. 


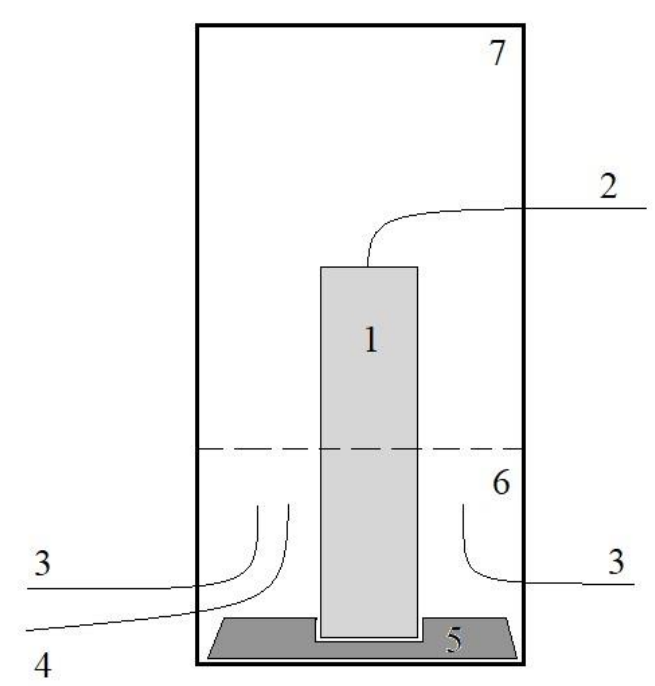

Figure 4. A device for recording polarization curves under pressure [74]: 1 - steel working electrode, 2 - platinum contact, 3 - platinum auxiliary electrodes, 4 - silver chloride electrode, 5 - fluoroplastic stand, 6 - $\mathrm{HCl}$ solution, 7 - transformer oil.

The electrical conductivity of $\mathrm{HCl}$ solutions at elevated temperatures and pressures was measured in an autoclave developed at the Grozny Research Institute (Figure 2) [75]. Its design was complemented by electrical inputs with platinum electrodes. Ohmic resistance was measured in the $\mathrm{Pt}|4 \mathrm{~N} \mathrm{HCl}| \mathrm{Pt}$ electrochemical circuit using an R-38 slide-wire bridge [76]. The set-up characteristics were: $t$ range up to $200^{\circ} \mathrm{C}, p$ range up to $500 \mathrm{~atm}$.

\section{Corrosion destruction of steels in acid solutions under high-temperature corrosion conditions}

Information on the corrosion resistance of steels in acid solutions is rather extensive, but, as a rule, it does not cover the high-temperature corrosion range. This determines the need for a systematic search for and analysis of information on the corrosion of steels in acid solutions under these conditions. Data on the corrosion of various structural metals, including steels, in mineral acids $\left(\mathrm{HCl}, \mathrm{H}_{2} \mathrm{SO}_{4}, \mathrm{H}_{3} \mathrm{PO}_{4}, \mathrm{HNO}_{3}, \mathrm{HF}\right)$ were collected and summarized in a reference book [77]. In total, the corrosion rates of steels are largely determined by their chemical composition, the nature of the acid, the concentration of acid solutions, their temperature, and duration of metal contact with the corrosive medium. Information on the corrosion rates of steels in solutions of mineral acids is limited by their boiling points. A brief review on the corrosion resistance of various steels in mineral $(\mathrm{HCl}$, $\mathrm{H}_{2} \mathrm{SO}_{4}, \mathrm{H}_{3} \mathrm{PO}_{4}, \mathrm{HNO}_{3}$, HF, sulfamic acid) and organic acids ( $\mathrm{HCOOH}$ and $\left.\mathrm{H}_{3} \mathrm{CCOOH}\right)$ is given in monograph [16]. The specific features of the corrosion behavior of stainless steels in solutions of mineral acids are discussed in [78], but high-temperature corrosion is not considered there, either. 


\section{Hydrochloric acid}

Studies on the dissolution rate of St3 steel (content in mass percent, \%: $0.14-0.22 \mathrm{C}$; up to $0.04 \mathrm{P}$; $0.15-0.33 \mathrm{Si}$; $0.40-0.65 \mathrm{Mn}$; up to $0.05 \mathrm{~S}$; up to $0.3 \mathrm{Cr}$; up to $0.3 \mathrm{Ni}$; up to 0.008 $\mathrm{N}$; up to $0.3 \mathrm{Cu}$; up to $0.08 \mathrm{As}$; remainder $\mathrm{Fe}$ ) in $8-20 \% \mathrm{HCl}$ in the range of $t=20-155^{\circ} \mathrm{C}$ and $p=1-500$ atm. made it possible to find a number of empirical laws describing this process [64]. Selected experimental data shown in Figure 5a indicate that corrosion of mild steel at $t>100^{\circ} \mathrm{C}$ occurs with high $k>1 \mathrm{~kg} /\left(\mathrm{m}^{2} \cdot \mathrm{h}\right)$. It is noted that the plot of $k$ for St3 steel $v s . t$ at a constant $p$ is approximately described by the Arrhenius equation:

$$
k=A \cdot \exp \left(-\frac{E}{R T}\right)
$$

where $A$ is an empirical constant; $E$ is the effective activation energy of the process that depends on the $\mathrm{HCl}$ content in the solution and the range of $t$ and $p ; R$ is the universal gas constant; and $T$ is the absolute temperature. Under experimental conditions, especially at elevated temperatures, this dependence was distorted due to a drop in $C_{\mathrm{HCl}}$ during the experiment and accumulation of a sludge layer on the metal surface. The dependence of $k$ on $C_{\mathrm{HCl}}$ at $p \leq 200 \mathrm{~atm}$. and $t \leq 155^{\circ} \mathrm{C}$ has the form:

$$
k=b\left(a_{\mathrm{HCl}}\right)^{n},
$$

where $a$ is the active concentration of $\mathrm{HCl} ; b$ and $n$ are empirical constants. At $p>200 \mathrm{~atm}$., upon an increase in $\mathrm{HCl}$ content in a solution to $20 \%$ the $k$ of steel decreases the stronger, the higher the values of $p$ and $t$. The value of $k$ decreases with an increase in $p$ :

$$
k=a+b \lg \frac{1}{p}
$$

where $a$ and $b$ are empirical constants. Under the same conditions, the corrosion of St5 steel (content in mass percent, \%: $0.28-0.37 \mathrm{C}$; up to $0.3 \mathrm{Si}$; $0.5-0.8 \mathrm{Mn}$; up to $0.05 \mathrm{~S}$; up to $0.04 \mathrm{P}$; remainder Fe) occurs with lower $k$ values (Figure $5 b$ ) [79].

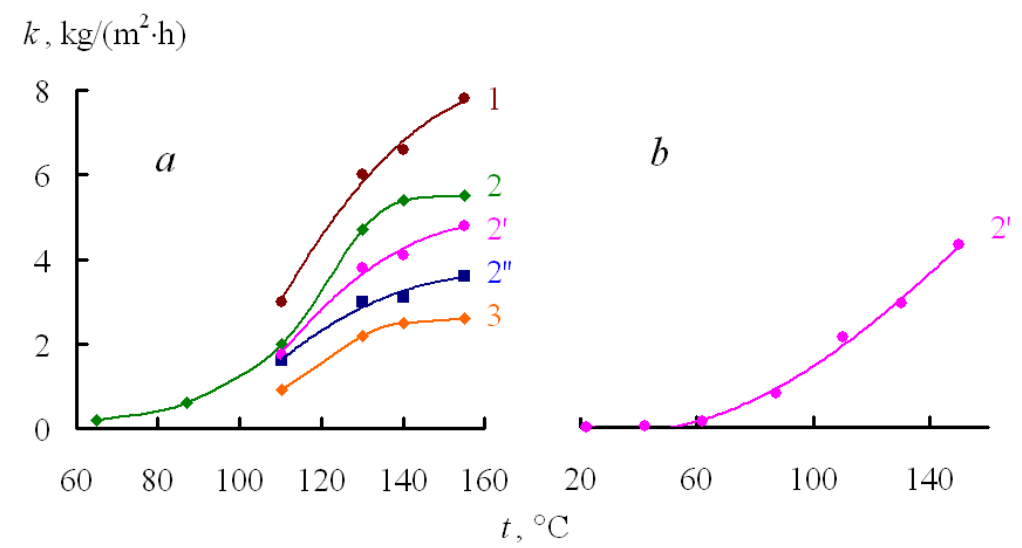

Figure 5. Corrosion rates of steel St3 (a) and steel St5 (b) in $\mathrm{HCl}$ solutions, wt.\%: $1-20 ; 2,2^{\prime}, 2^{\prime \prime}$ $-16 ; 3-8$. Pressure, atm.: $1,2,3-100 ; 2^{\prime}-300$ and $2^{\prime \prime}-500$. Test duration $-0.5 \mathrm{~h}$ at $t=65^{\circ} \mathrm{C}$. 
More detailed data on the corrosion of steels in hydrochloric acid were obtained by N.I. Podobaev and V.V. Vasil'ev [80]. They studied the corrosion of St1 low-carbon steel (content in mass percent, \%: $0.07 \mathrm{C}, 0.022 \mathrm{P}$; $0.02 \mathrm{Si}$; $0.027 \mathrm{~S}$; remainder $\mathrm{Fe}$ ) in $4 \mathrm{M} \mathrm{HCl}$ in the range of $t=110-250^{\circ} \mathrm{C}$. In the studies on the mass loss of samples, the mean $k$ of the metal was determined (Figure 6a):

$$
k_{\mathrm{av}}=\frac{\Delta m \cdot 60 \cdot 10^{4}}{S \tau}
$$

where $\Delta m$ is the mass loss of a steel sample, $S$ is the area of the sample in $\mathrm{cm}^{2} \cdot \mathrm{m}$ and $\tau$ is time. It was noted that in the selected $t$ range, the values of $k$ became large and, even after contact of the acid with the metal for 3-10 min, the acid concentration decreased by a factor of 2-7. Therefore, the mean $k$ of steel does not at all match the true rate at the initial acid concentration. For this reason, it was necessary to calculate the differential corrosion rate as for a first-order reaction. The rate constant of the reaction of hydrochloric acid with steel was determined from the decrease in concentration, $C$ (in $\mathrm{mol} / \mathrm{l}$ ):

$$
K_{\mathrm{HCl}}=\frac{2.303}{\tau} \lg \frac{C}{C-X}
$$

where $\tau$ is the time from the start of the experiment, min; $C-X$ is the acid concentration at the end of the experiment. If the corrosion rate of steel in expressed in $\mathrm{g} /\left(\mathrm{m}^{2} \cdot \mathrm{h}\right)$, the rate constant of steel dissolution (Figure 6b) is equal to:

$$
K_{\mathrm{St}}=K_{\mathrm{HCl}} \cdot \frac{M\left(\frac{1}{Z} F e\right) \cdot 10^{4} \cdot 60 \cdot V}{S}
$$

where $M\left(\frac{1}{Z} F e\right)$ is the equivalent mass of iron and $S / V$ is the metal area in $\mathrm{cm}^{2}$ per 1 liter of the acid solution. The differential corrosion rate is related to the dissolution rate constant of steel by the relationship:

$$
k_{\mathrm{dif}}=K_{\mathrm{St}} \cdot C^{\mathrm{x}}
$$

where $x$ is an empirical coefficient that depends on the reaction mechanism. One can see that the differential $k$ values of steel are significantly higher than the mean values.

Analysis of the dependence of $\log K_{\mathrm{St}}$ on $T^{-1}$ (Figure 6b) showed that at $t$ up to $190^{\circ} \mathrm{C}$, it is linear and the corrosion process is described by the Arrhenius equation. The effective activation energy of the corrosion process is $E_{\mathrm{a}}=36 \mathrm{~kJ} / \mathrm{mol}$, which is typical of a mixed diffusion-kinetic control of the process. At higher $t$, this dependence becomes irregular. Extrapolation of the linear portion of this dependence to higher $t$ allowed the true values of steel corrosion rate to be calculated from the corrected $K_{\mathrm{St}}$ values (Figure 6a). They are significantly higher than the differential values at $t \geq 210^{\circ} \mathrm{C}$. According to the authors, this is a consequence of the acid consumption due to corrosion that decreases its concentration. 
In addition, its decrease in the near-electrode layer at these high temperatures causes the hydrolysis of the corrosion product, $\mathrm{FeCl}_{2}$. At $t=150-200^{\circ} \mathrm{C}$, dehydration of hydrolysis products becomes possible. As a result, the samples become coated with a black film consisting of $\mathrm{FeO}$ and $\mathrm{Fe}(\mathrm{OH}) \mathrm{Cl}$ (mass ratio 1.9:1) that inhibits corrosion. The composition of the film was confirmed by chemical analysis. An increase in pressure slows down the corrosion of St1 steel over the entire selected $t$ range.
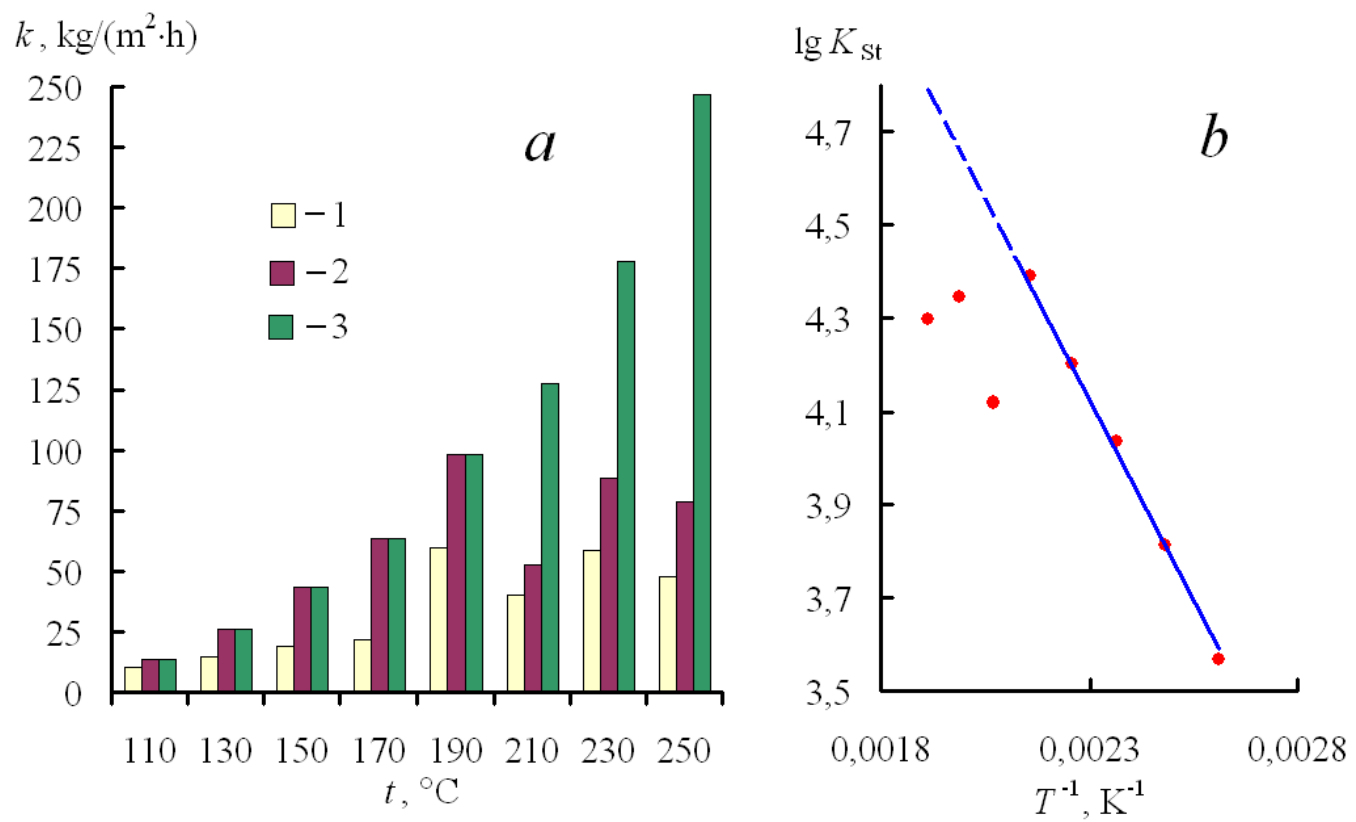

Figure 6. Mean (1), differential (2) and true (3) corrosion rates of St1 steel in $4 \mathrm{M} \mathrm{HCl} \mathrm{(a)} \mathrm{and}$ the variation of $\log K_{\mathrm{St}} v s T^{-1}$ for the same process $(b)$. The points represent experimental values; the line is a simulation according to the Arrhenius equation. Test duration $-10 \mathrm{~min}$ at $t \leq 170^{\circ} \mathrm{C}$ and $3 \mathrm{~min}$ at $t \geq 190^{\circ} \mathrm{C}$. Pressure $-300 \mathrm{~atm}$.

Under the same conditions, 36G2S steel (content in mass percent, \%: $0.47 \mathrm{C} ; 0.022 \mathrm{P}$; $0.019 \mathrm{Si}$; $0.70 \mathrm{Mn}$; $0.030 \mathrm{~S}$; $0.05 \mathrm{Cr}$; $0.06 \mathrm{Ni}$; remainder $\mathrm{Fe}$ ) used to make pumpcompressor pipes is more resistant to the exposure to the acid. At $110^{\circ} \mathrm{C}$ and $p=100 \mathrm{~atm}$, the mean and differential $k$ values of steel are 3.44 and $4.00 \mathrm{~kg} /\left(\mathrm{m}^{2} \cdot \mathrm{h}\right)$, while at $230^{\circ} \mathrm{C}$ they are 41.8 and $68.7 \mathrm{~kg} /\left(\mathrm{m}^{2} \cdot \mathrm{h}\right)$, respectively. Raising the pressure to $500 \mathrm{~atm}$ slows down the corrosion. The mean and differential $k$ values of steel at $110^{\circ} \mathrm{C}$ are 2.22 and $2.48 \mathrm{~kg} /\left(\mathrm{m}^{2} \cdot \mathrm{h}\right)$, and those at $230^{\circ} \mathrm{C}$ are 33.8 and $48.7 \mathrm{~kg} /\left(\mathrm{m}^{2} \cdot \mathrm{h}\right)$.

This study shows that the mean values of $k$ experimentally obtained from the mass loss of steel samples are significantly lower than the true values, which does not allow one to fully estimate the corrosiveness of the medium that is much higher. Perhaps, this effect is hard to notice in a laboratory set-up where corrosion occurs in a limited volume of an acid that is quickly consumed, but the corrosion losses will be much higher in pipelines where the pumped acid is constantly renewed. 
Later, A.K. Iskhakov and F.K. Kurbanov [81] conducted a systematic study of the corrosion of steel 20 (content in mass percent, \%: 0.17-0.24 C; 0.17-0.37 Si; 0.35-0.65 $\mathrm{Mn}$; up to $0.30 \mathrm{Ni}$; up to $0.30 \mathrm{Cu}$; up to $0.25 \mathrm{Cr}$; up to $0.08 \mathrm{As}$; up to $0,035 \mathrm{P}$; up to $0.04 \mathrm{~S}$; remainder $\mathrm{Fe})$ in $15 \% \mathrm{HCl}$ where $k$ was $5.14 \mathrm{~kg} /\left(\mathrm{m}^{2} \cdot \mathrm{h}\right)$ at $110^{\circ} \mathrm{C}, 7.45 \mathrm{~kg} /\left(\mathrm{m}^{2} \cdot \mathrm{h}\right)$ at $120^{\circ} \mathrm{C}$, $9.54 \mathrm{~kg} /\left(\mathrm{m}^{2} \cdot \mathrm{h}\right)$ at $130^{\circ} \mathrm{C}, 12.1 \mathrm{~kg} /\left(\mathrm{m}^{2} \cdot \mathrm{h}\right)$ at $140^{\circ} \mathrm{C}, 17.2 \mathrm{~kg} /\left(\mathrm{m}^{2} \cdot \mathrm{h}\right)$ at $150^{\circ} \mathrm{C}$ and $20.1 \mathrm{~kg} /\left(\mathrm{m}^{2} \cdot \mathrm{h}\right)$ at $160^{\circ} \mathrm{C}$. The corrosion of steel D (content in mass percent, \%: $0.41-0.48$ $\mathrm{C}$; $0.17-0.37 \mathrm{Si}$; $0.65-0.90 \mathrm{Mn}$; up to $0.045 \mathrm{~S}$; $0.045 \mathrm{P} ; 0.25 \mathrm{Cu}$; remainder $\mathrm{Fe}$ ) in $12 \%$ $\mathrm{HCl}$ at 100,140 and $160^{\circ} \mathrm{C}(p=30 \mathrm{MPa})$ occurs with following rates: 2.82, 3.80 and $4.22 \mathrm{~kg} /\left(\mathrm{m}^{2} \cdot \mathrm{h}\right)$, respectively [82].

Less systematic data were obtained for the corrosion of steel $\mathrm{N} 80$ in $15 \% \mathrm{HCl}$ (content in mass percent, \%: $0.34-0.38 \mathrm{C}$; $0.20-0.35 \mathrm{Si} ; 1.45-1.7 \mathrm{Mn}$; P up to 0.02 ; $\mathrm{S}$ up to 0.015 ; Cr up to $0.15 ; 0.11-0.16 \mathrm{~V}$; remainder Fe). According to S. Vishwanatham et al., at $110^{\circ} \mathrm{C}(1.22 \mathrm{~atm}, 1 \mathrm{~h})$ the $k$ value is significant: $0.67 \mathrm{~kg} /\left(\mathrm{m}^{2} \cdot \mathrm{h}\right)$ [83], while at $115^{\circ} \mathrm{C}$ $(1.22 \mathrm{~atm}, 1 \mathrm{~h})$ it is $0.69 \mathrm{~kg} /\left(\mathrm{m}^{2} \cdot \mathrm{h}\right)$ [84]. According to M. Kuraishi, $k=2.6 \mathrm{~kg} /\left(\mathrm{m}^{2} \cdot \mathrm{h}\right)$ at $105^{\circ} \mathrm{C}$ (the time of metal contact with the acid is not reported) [85], which is significantly higher than in the previous studies. Under these conditions, corrosion slows down with time. According to the tests, $k=2.8 \mathrm{~kg} /\left(\mathrm{m}^{2} \cdot \mathrm{h}\right)$ for $0.5 \mathrm{~h}, 2.1 \mathrm{~kg} /\left(\mathrm{m}^{2} \cdot \mathrm{h}\right)$ for $3 \mathrm{~h}$, and $1.6 \mathrm{~kg} /\left(\mathrm{m}^{2} \cdot \mathrm{h}\right)$ for $6 \mathrm{~h}[86]$.

For cold-rolled mild steel (content in mass percent, \%: $0.14 \mathrm{C} ; 0.35 \mathrm{Mn} ; 0.17 \mathrm{Si}$; $0.025 \mathrm{~S} ; 0.03 \mathrm{P}$; remainder $\mathrm{Fe})$ at $105^{\circ} \mathrm{C}, k=12.8[86,87]$ and $39.5[88] \mathrm{kg} /\left(\mathrm{m}^{2} \cdot \mathrm{h}\right)$. For mild steel AISI 1079 (content in mass percent, \%: $0.14 \mathrm{C} ; 0.35 \mathrm{Mn} ; 0.17 \mathrm{Si} ; 0.025 \mathrm{~S} ; 0.03$ $\mathrm{P}$; remainder $\mathrm{Fe})$ under the same conditions, $k=11.1 \mathrm{~kg} /\left(\mathrm{m}^{2} \cdot \mathrm{h}\right)$ [89]. For mild steel (content in mass percent, \%: $0.270 \mathrm{C} ; 0.340 \mathrm{Mn} ; 0.080 \mathrm{Si} ; 0.006 \mathrm{~S} ; 0.008 \mathrm{P}$; remainder $\mathrm{Fe}$ ) in $15 \% \mathrm{HCl}\left(105^{\circ} \mathrm{C}\right), k=0.38 \mathrm{~kg} /\left(\mathrm{m}^{2} \cdot \mathrm{h}\right)$, which we believe to be significantly lower than the true value [90].

It should be noted that the data discussed above are rather contradictory. In different articles of the same authors and under the same conditions and with the same steel grade, the values of $k$ differ at least several times. Perhaps this is the result of different preliminary thermal or mechanical treatment of metal samples, but the observed differences are too considerable. Probably, random errors in the design of the experiment or its treatment affect the results in some cases. More objective and accurate information concerning the metal corrosion rates at elevated temperatures could be given not by measurements at specific temperatures but by corrosion studies in a wide temperature range. Data on the corrosion of various steels in $\mathrm{HCl}$ solutions in a temperature range including high-temperature regions are presented in [91-96] (Figure 7). Unfortunately, they contain the corrosion rates of steels related to 3 or 4 temperatures. In the corrosion of carbon steel (content in mass percent,\%: $0.14 \mathrm{C}$; $0.35 \mathrm{Mn} ; 0.17 \mathrm{Si} ; 0.025 \mathrm{~S}$; $0.03 \mathrm{P}$; remainder $\mathrm{Fe}$ ) in $15 \% \mathrm{HCl}$, the effective activation energy of corrosion was found to be $46.3 \mathrm{~kJ} / \mathrm{mol}$ [91], which is typical of a process with mixed kinetics. 


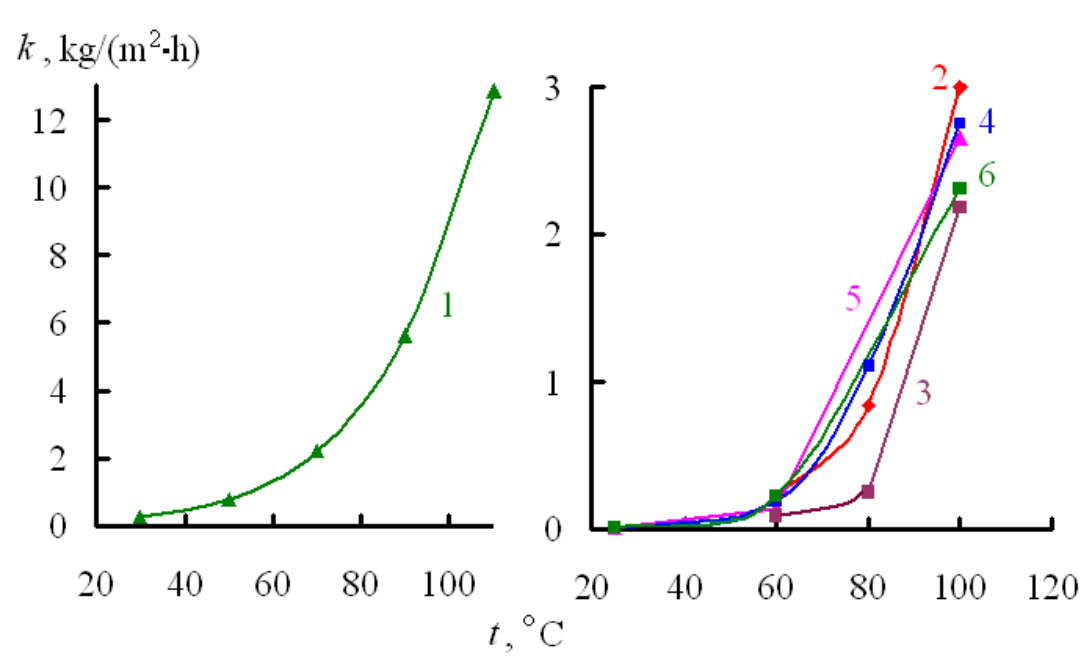

Figure 7. Corrosion rates of steel in $\mathrm{HCl}$ solutions: 1 - carbon steel, $15 \% \mathrm{HCl}$, test duration - 6 h [91]; 2 - steel St3, $4 \mathrm{M} \mathrm{HCl}$ [92]; 3 - steel 10, $4 \mathrm{M} \mathrm{HCl}$, test duration - $1 \mathrm{~h}$ [93]; 4 - steel 10, $4 \mathrm{M} \mathrm{HCl}$, test duration - 1-4 h [94]; 5 - steel 10, $4 \mathrm{M} \mathrm{HCl} \mathrm{[95];} \mathrm{6} \mathrm{-} \mathrm{low}$ carbon steel, $4 \mathrm{M} \mathrm{HCl}[96]$.

In [67], more detailed information is given on the corrosion of steel $20 \mathrm{in} \mathrm{HCl}$ solutions in a wide range of temperatures, $t=0-160^{\circ} \mathrm{C}$, and acid concentrations, $C_{\mathrm{HCl}}=2-6 \mathrm{M}$ (Table 1). In $2 \mathrm{M} \mathrm{HCl}$, corrosion increases systematically with an increase in $t$. Its growth from 0 to $160^{\circ} \mathrm{C}$ in tests for $30 \mathrm{~min}$ increases $k$ by a factor of 3100 . At $t \geq 100^{\circ} \mathrm{C}$, the mass loss of steel exceeds $1 \mathrm{~kg} /\left(\mathrm{m}^{2} \cdot \mathrm{h}\right)$. The value of $k$ decreases with time, which is a result of the acid consumption in the solution with time. In the range of $t=0-100^{\circ} \mathrm{C}$, an increase in the duration of corrosion tests from 0.5 to $1.0 \mathrm{~h}$ reduces the mean $k$ value by a factor of $1.01-$ 1.60 , and at 2.0 hours, by a factor of 1.08-2.11. Moreover, with an increase in $t$, the difference in $k$ decreases with time. An increase in $C_{\mathrm{HCl}}$ causes an increase in the corrosion rate. In $2 \mathrm{M} \mathrm{HCl}$, the effective activation energy of the corrosion process is $56 \pm 3 \mathrm{~kJ} / \mathrm{mol}$, which is higher than in the cases that we considered. This result indicates that corrosion involves a large kinetic component under the experimental conditions.

Unique data on the high-temperature corrosion of nickel-chromium steels are available [69]. In cold $2 \mathrm{M} \mathrm{HCl}\left(t=0^{\circ} \mathrm{C}\right), 08 \mathrm{Kh} 18 \mathrm{~N} 10 \mathrm{~T}$ steel (content in mass percent, \%: $0.08 \mathrm{C}$; $17-19 \mathrm{Cr}$; $9-11 \mathrm{Ni}$; $0.8 \mathrm{Si}$; up to $2 \mathrm{Mn}$; up to $0.02 \mathrm{~S}$; up to $0.035 \mathrm{P}$; up to $0.3 \mathrm{Cu}$; up to $0.7 \mathrm{Ti}$; remainder $\mathrm{Fe}$ ) is relatively stable, and the maximum observed $k$ is $0.68 \mathrm{~g} /\left(\mathrm{m}^{2} \cdot \mathrm{h}\right)$. However, in this medium, steel corrosion accelerates with increasing $t$ and after $0.5 \mathrm{~h}$ of testing, it is $0.10 \mathrm{~kg} /\left(\mathrm{m}^{2} \cdot \mathrm{h}\right)$ at $80^{\circ} \mathrm{C},-0.32 \mathrm{~kg} /\left(\mathrm{m}^{2} \cdot \mathrm{h}\right)$ at $100^{\circ} \mathrm{C}$, and reaches $5.0 \mathrm{~kg} /\left(\mathrm{m}^{2} \cdot \mathrm{h}\right)$ at $160^{\circ} \mathrm{C}$ (Table 1$)$. Like in the case of mild steel, its corrosion intensifies with increasing acid content in the solution and slows down in longer corrosion tests. As one can see from the study results, chromium-nickel steel 08Kh18N10T belonging to the group of so-called "stainless steels" is unstable in hot $\mathrm{HCl}$ solutions, and at $t \geq 120^{\circ} \mathrm{C}$ the corrosion rate should be measured in $\mathrm{kg} /\left(\mathrm{m}^{2} \cdot \mathrm{h}\right)$. 
Table 1. Corrosion rates* $\left(k, \mathrm{~kg} /\left(\mathrm{m}^{2} \cdot \mathrm{h}\right)\right)$ of steel 20 and $08 \mathrm{Kh} 18 \mathrm{~N} 10 \mathrm{~T}$ steel in $\mathrm{HCl}$ solutions at various temperatures.

\begin{tabular}{|c|c|c|c|c|c|c|}
\hline \multirow{3}{*}{$\begin{array}{c}\text { Temperature, } \\
{ }^{\circ} \mathrm{C}\end{array}$} & \multicolumn{6}{|c|}{ Test duration } \\
\hline & $0.5 \mathrm{~h}$ & $1.0 \mathrm{~h}$ & $2.0 \mathrm{~h}$ & $0.5 \mathrm{~h}$ & $1.0 \mathrm{~h}$ & $2.0 \mathrm{~h}$ \\
\hline & \multicolumn{3}{|c|}{ Steel 20} & \multicolumn{3}{|c|}{ 08Kh18N10T steel } \\
\hline \multicolumn{7}{|c|}{$2 \mathrm{M} \mathrm{HCl}$} \\
\hline 0 & 0.0040 & 0.0023 & 0.0012 & 0.00068 & 0.00064 & 0.00057 \\
\hline 20 & 0.0098 & 0.0089 & 0.0056 & 0.0017 & 0.0013 & 0.00096 \\
\hline 40 & 0.038 & 0.032 & 0.028 & 0.015 & 0.013 & 0.0080 \\
\hline 60 & 0.091 & 0.085 & 0.083 & 0.032 & 0.026 & 0.021 \\
\hline 80 & 0.40 & 0.40 & 0.37 & 0.10 & 0.087 & 0.072 \\
\hline 100 & 1.55 & 1.52 & 1.40 & 0.32 & 0.41 & 0.55 \\
\hline 120 & 4.99 & 4.15 & - & 1.90 & 1.40 & - \\
\hline 140 & 8.06 & - & - & 2.70 & - & - \\
\hline 160 & 12.4 & - & - & 5.00 & - & - \\
\hline \multicolumn{7}{|c|}{$4 \mathrm{M} \mathrm{HCl}$} \\
\hline 100 & 3.38 & 3.10 & 2.72 & - & - & - \\
\hline 120 & 6.63 & - & - & - & - & - \\
\hline 140 & 12.0 & - & - & 7.90 & - & - \\
\hline \multicolumn{7}{|c|}{$6 \mathrm{M} \mathrm{HCl}$} \\
\hline 100 & 4.97 & 4.61 & 4.02 & - & - & - \\
\hline 120 & 9.34 & - & - & - & - & - \\
\hline 140 & - & - & - & 10.0 & - & - \\
\hline
\end{tabular}

* The $k$ values were calculated from the loss of mass of metal samples.

It seems interesting to compare the corrosion resistance in hot $\mathrm{HCl}$ solutions of the above-mentioned iron-based alloys and the new corrosion-resistant alloys suggested for manufacturing items to be operated in these environments. Data on the corrosion of Nibased commercial alloys (6 alloys) in $20 \% \mathrm{HCl}\left(92^{\circ} \mathrm{C}\right)$ are reported $[97,98]$. The required $k \leq 0.45 \mathrm{~g} /\left(\mathrm{m}^{2} \cdot \mathrm{h}\right)$ was provided without additional protective measures only by the UNS N10675 alloy (content in mass percent, \%: $28.5 \mathrm{Mo}$; $1.5 \mathrm{Cr}$; remainder Ni). For alloys with lower Mo content and high $\mathrm{Cr}$ content, the $k$ value reached $6.6 \mathrm{~g} /\left(\mathrm{m}^{2} \cdot \mathrm{h}\right)$. One can see that the corrosion rates of iron alloys are thousands of times higher than those of nickel alloys, however, not only the corrosion resistance of a material but also its cost are considered in 
industrial applications. It is not quite clear how the new alloys will behave in terms of corrosion at $t>100^{\circ} \mathrm{C}$.

More complete information on the mechanism of the corrosion of steels in $\mathrm{HCl}$ solutions at elevated $t$ might be given by voltammetric studies of the cathodic and anodic electrode processes occurring on a metal under these conditions. Paper [72] reports the results of voltammetric studies on the behavior of steel 20 in $2 \mathrm{M} \mathrm{HCl}$ in the range of $t=20-100^{\circ} \mathrm{C}$ (Figure 8) that covers a lower region of high-temperature corrosion. In $2 \mathrm{M}$ $\mathrm{HCl}$, steel is in the active dissolution state in the entire $t$ range studied, and its free corrosion potential $\left(E_{\mathrm{cor}}\right)$ does not depend on $t$ considerably. In the entire $t$ range under consideration, the anodic polarization curves are characterized by a limiting current due to the formation of a sludge layer on the metal surface, which partially shields the steel surface and hinders the supply of the starting reagents to the metal surface or removal of the reaction products. At $t \leq 60^{\circ} \mathrm{C}$, the cathodic polarization slope is $0.120 \mathrm{~V}$. However, a limiting current is observed at higher $t$, which is a consequence of the presence of sludge on the metal surface and abundant evolution of gaseous hydrogen that shields the surface. An increase in $t$ results in a consistent increase in cathodic and anodic currents, but, starting from $t=80^{\circ} \mathrm{C}$, the electrode reaction rates grow much more slowly. Apparently, sludge formation and evolution of gaseous hydrogen on the metal surface are accelerated with an increase in $t$, which slows down the electrode processes. The higher the $t$ value, the more significant the effect of sludge formation and gas evolution on the electrode reactions of steel becomes. The hindering effect of these processes on the electrode reactions of steel is indirectly confirmed by data on the kinetics of hydrogen evolution on an inert mercury electrode in this medium [73]. In $1 \mathrm{M} \mathrm{HCl}\left(123-302^{\circ} \mathrm{C}\right)$, a systematic increase in the rate of the cathodic reaction occurs with an increase in $t$, which we do not observe on steel whose surface is partially shielded from the corrosive medium by sludge and gaseous hydrogen.
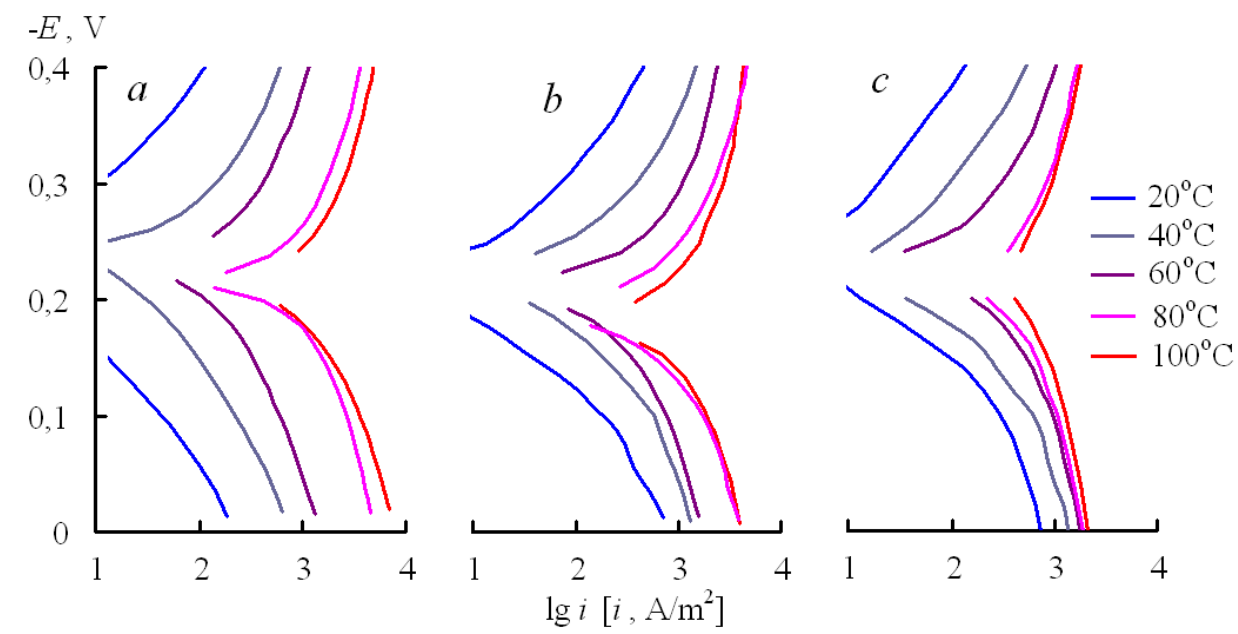

Figure 8. Polarization curves of steel 20 in $2.0 \mathrm{M} \mathrm{HCl}(a)$, steel 20 in $2.0 \mathrm{M} \mathrm{H}_{2} \mathrm{SO}_{4}(b)$ and steel $\mathrm{St} 3$ in $2.0 \mathrm{M} \mathrm{H}_{3} \mathrm{PO}_{4}(c)$. 
The formation of sludge and the release of gaseous hydrogen less strongly affect the electrode reactions on $12 \mathrm{Kh} 18 \mathrm{~N} 10 \mathrm{~T}$ chromium-nickel steel (content in mass percent, up to $0.12 \mathrm{C}$; up to $0.8 \mathrm{Si}$; up to $2 \mathrm{Mn}$; $9-11 \mathrm{Ni}$; up to $0.02 \mathrm{~S}$; up to $0.035 \mathrm{P} ; 17-19 \mathrm{Cr}$; up to $0.3 \mathrm{Cu}$; up to $0.5 \mathrm{Ti}$; remainder $\mathrm{Fe})$ [99]. In $2 \mathrm{M} \mathrm{HCl}\left(t=20-100^{\circ} \mathrm{C}\right)$, this steel is in the active dissolution region, and the cathodic and anodic polarization slopes are 0.10 and $0.07-0.08 \mathrm{~V}$, respectively. It is noted here that certain changes in the electrochemical behavior of steel over time and with an increase in $t$ result from the enrichment of the metal surface with the most inert alloy component, $\mathrm{Ni}$, during the corrosion process.

Thus, the data of electrochemical studies are in good agreement with the results obtained from the mass loss of corroded samples. Both methods show that the partial electrode reactions of steel and, as a result, the total corrosion process in $\mathrm{HCl}$ solutions at elevated $t$ are substantially distorted by the sludge formation and evolution of gaseous hydrogen. As a result, the rates of electrode reactions and corrosion process obtained experimentally will be significantly lower than the true values. This fact should be taken into account in calculations of the protective effects of various inhibitors under these conditions, since they will be underestimated.

\section{Sulfuric acid}

Information on the high-temperature corrosion of steels in sulfate environments available in the literature is more limited than for $\mathrm{HCl}$. The review [100] and article [101] provide information on the corrosion of carbon and chromium-nickel steels in concentrated $\mathrm{H}_{2} \mathrm{SO}_{4}$. It should be remembered here that these materials are significantly more resistant in concentrated $\mathrm{H}_{2} \mathrm{SO}_{4}$ than in its aqueous solutions, which makes it possible to perform studies in these media. There is practically no studies on steel corrosion in $\mathrm{H}_{2} \mathrm{SO}_{4}$ solutions at $t \geq 100^{\circ} \mathrm{C}$ and information reported in literature is limited at best to temperatures up to $90^{\circ} \mathrm{C}[102,103]$. Therefore, the data on the corrosion of steel 20 in $2 \mathrm{M} \mathrm{H}_{2} \mathrm{SO}_{4}$ reported in [66] are of special interest. According to these data, the corrosion of steel in this medium increases significantly with increasing $t$ (Table 2), and its increase from 0 to $200^{\circ} \mathrm{C}$ results in an increase in $k$ by a factor of 1610 . The corrosion losses at $t>80^{\circ} \mathrm{C}$ are measured in $\mathrm{kg} /\left(\mathrm{m}^{2} \cdot \mathrm{h}\right)$. The value of $k$ slightly decreases with time. In the range of $t=0-100^{\circ} \mathrm{C}$, an increase in the duration of corrosion tests from 0.5 to $1.0 \mathrm{~h}$ reduces the mean $k$ by a factor of $1.03-1.25$, and at 2.0 hours, by a factor of $1.11-1.41$. The effective activation energy of the corrosion process is $41 \pm 2 \mathrm{~kJ} / \mathrm{mol}$. In a similar environment, the $k$ of St3 steel was $0.78 \mathrm{~kg} /\left(\mathrm{m}^{2} \cdot \mathrm{h}\right)$ at $80^{\circ} \mathrm{C}, \quad 2.74 \mathrm{~kg} /\left(\mathrm{m}^{2} \cdot \mathrm{h}\right)$ at $100^{\circ} \mathrm{C}, \quad 3.23 \mathrm{~kg} /\left(\mathrm{m}^{2} \cdot \mathrm{h}\right)$ at $120^{\circ} \mathrm{C}$ and $3.84 \mathrm{~kg} /\left(\mathrm{m}^{2} \cdot \mathrm{h}\right)$ at $140^{\circ} \mathrm{C}$ [104]. The corrosion rate of this steel increased more slowly at $t>100^{\circ} \mathrm{C}$ due to faster evolution of gaseous hydrogen on the metal surface and active sludge formation.

Chromium-nickel steel $08 \mathrm{Kh} 18 \mathrm{~N} 10 \mathrm{~T}$ is not resistant to the action of hot $2 \mathrm{M} \mathrm{H}_{2} \mathrm{SO}_{4}$, either (Table 2). $08 \mathrm{Kh} 18 \mathrm{~N} 10 \mathrm{~T}$ steel is rather stable in a cold $\mathrm{H}_{2} \mathrm{SO}_{4}$ solution $\left(t=0^{\circ} \mathrm{C}\right)$ and the maximum observed $k$ is $0.34 \mathrm{~g} /\left(\mathrm{m}^{2} \cdot \mathrm{h}\right)$, whereas, according to $0.5 \mathrm{~h}$ tests, $k$ is 
$0.3 \mathrm{~kg} /\left(\mathrm{m}^{2} \cdot \mathrm{h}\right)$ already at $80^{\circ} \mathrm{C},-0.7 \mathrm{~kg} /\left(\mathrm{m}^{2} \cdot \mathrm{h}\right)$ at $100^{\circ} \mathrm{C}$, and reaches $9.7 \mathrm{~g} /\left(\mathrm{m}^{2} \cdot \mathrm{h}\right)$ at $200^{\circ} \mathrm{C}$. An increase in the acid concentration in the background solution considerably increases its corrosivity. At $t=160^{\circ} \mathrm{C}$, a twofold increase in the acid content in the solution accelerates corrosion almost 2.5-fold [105].

Table 2. Corrosion rates* $\left(k, \mathrm{~kg} /\left(\mathrm{m}^{2} \cdot \mathrm{h}\right)\right)$ of steel 20 and $08 \mathrm{Kh} 18 \mathrm{~N} 10 \mathrm{~T}$ steel in $\mathrm{H}_{2} \mathrm{SO}_{4}$ solutions at various temperatures.

\begin{tabular}{|c|c|c|c|c|c|c|}
\hline \multirow{3}{*}{$\begin{array}{c}\text { Temperature, } \\
{ }^{\circ} \mathbf{C}\end{array}$} & \multicolumn{6}{|c|}{ Test duration } \\
\hline & $0.5 \mathrm{~h}$ & $1.0 \mathrm{~h}$ & $2.0 \mathrm{~h}$ & $0.5 \mathrm{~h}$ & $1.0 \mathrm{~h}$ & $2.0 \mathrm{~h}$ \\
\hline & \multicolumn{3}{|c|}{ Steel 20} & \multicolumn{3}{|c|}{ 08Kh18N10T steel } \\
\hline \multicolumn{7}{|c|}{$2 \mathrm{M} \mathrm{H}_{2} \mathrm{SO}_{4}$} \\
\hline 0 & 0.0095 & 0.012 & 0.0086 & 0.00032 & 0.00034 & 0.00027 \\
\hline 20 & 0.045 & 0.036 & 0.033 & 0.0050 & 0.0035 & 0.0034 \\
\hline 40 & 0.105 & 0.095 & 0.093 & 0.022 & 0.021 & 0.017 \\
\hline 60 & 0.35 & 0.34 & 0.315 & 0.056 & 0.063 & 0.087 \\
\hline 80 & 0.883 & 0.835 & 0.742 & 0.297 & 0.204 & 0.265 \\
\hline 100 & 2.26 & 2.04 & 1.74 & 0.706 & 0.877 & 0.851 \\
\hline 120 & 3.16 & 2.93 & 2.24 & 1.17 & 1.29 & 0.909 \\
\hline 140 & 4.04 & - & - & 1.90 & 2.02 & - \\
\hline 160 & 6.78 & - & - & 4.01 & - & - \\
\hline 180 & 10.1 & - & - & 6.37 & - & - \\
\hline 200 & 15.3 & - & - & 9.74 & - & - \\
\hline \multicolumn{7}{|c|}{$4 \mathrm{M} \mathrm{H}_{2} \mathrm{SO}_{4}$} \\
\hline 160 & - & - & - & 9.90 & - & - \\
\hline \multicolumn{7}{|c|}{$6 \mathrm{M} \mathrm{H}_{2} \mathrm{SO}_{4}$} \\
\hline 160 & - & - & - & 12.5 & - & - \\
\hline
\end{tabular}

$* k$ values are calculated from the loss of mass of metal samples.

A voltammetric study of steel 20 corrosion in $2 \mathrm{M} \mathrm{H}_{2} \mathrm{SO}_{4}\left(20-100^{\circ} \mathrm{C}\right)$ [72] showed that in the entire selected $t$ range, the metal was in the active dissolution region. An increase in the solution temperature shifts the steel corrosion potential $\left(E_{\text {cor }}\right)$ towards more positive values. Due to the formation of a sludge layer on the metal surface, the $b_{\text {a }}$ slope increases systematically to a limiting current with an increase in $t$. The abundant sludge formation and the evolution of gaseous hydrogen observed on the electrodes increase the $b_{\mathrm{c}}$ slope up to the limiting currents observed at $t \geq 60^{\circ} \mathrm{C}$. The $i_{\mathrm{c}}$ and $i_{\mathrm{a}}$ values increase with $t$, 
but their growth slows down considerably at $t>80^{\circ} \mathrm{C}$. The observed picture is quite close to that reported in $\mathrm{HCl}$ solutions. In $2 \mathrm{M} \mathrm{H}_{2} \mathrm{SO}_{4}\left(20-100^{\circ} \mathrm{C}\right), 12 \mathrm{Kh} 18 \mathrm{~N} 10 \mathrm{~T}$ chromiumnickel steel is also in the active dissolution region, but the nature of the cathodic and anodic processes on the metal is more complicated due to the multicomponent nature of the metal alloy, as discussed in [106].

\section{Phosphoric acid}

The recent special studies on the corrosion behavior of various steels in $\mathrm{H}_{3} \mathrm{PO}_{4}[107,108]$ do not cover the region of their high-temperature corrosion. Only in [109], data on the corrosion of St3 low-carbon steel in $2 \mathrm{M} \mathrm{H}_{3} \mathrm{PO}_{4}\left(0-95^{\circ} \mathrm{C}\right)$ are reported. The $k$ of steel is $2.4 \mathrm{~g} /\left(\mathrm{m}^{2} \cdot \mathrm{h}\right)$ at $0^{\circ} \mathrm{C}, 5.8 \mathrm{~g} /\left(\mathrm{m}^{2} \cdot \mathrm{h}\right)$ at $25^{\circ} \mathrm{C}, 20.2 \mathrm{~g} /\left(\mathrm{m}^{2} \cdot \mathrm{h}\right)$ at $40^{\circ} \mathrm{C}, 37.9 \mathrm{~g} /\left(\mathrm{m}^{2} \cdot \mathrm{h}\right)$ at $60^{\circ} \mathrm{C}$, $141 \mathrm{~g} /\left(\mathrm{m}^{2} \cdot \mathrm{h}\right)$ at $80^{\circ} \mathrm{C}$ and $518 \mathrm{~g} /\left(\mathrm{m}^{2} \cdot \mathrm{h}\right)$ at $95^{\circ} \mathrm{C}$, which are lower than the values for lowcarbon steels in $2 \mathrm{M} \mathrm{H}_{2} \mathrm{SO}_{4}$ and $2 \mathrm{M} \mathrm{HCl}$ under the same conditions. In general, it can be predicted that with a further increase in the temperature of $\mathrm{H}_{3} \mathrm{PO}_{4}$ solutions, the corrosion losses of steel will quickly exceed $1 \mathrm{~kg} /\left(\mathrm{m}^{2} \cdot \mathrm{h}\right)$. The plots of $k$ of steel versus $t$ are formally described by the Arrhenius equation and the effective activation energy of the corrosion process is $46 \pm 1 \mathrm{~kJ} / \mathrm{mol}$, which indicates that the reaction occurs in a mixed kinetics mode. Electrochemical studies [110] performed under the same conditions showed (Figure 8c) that the $E$ value for steel corrosion does not considerably depend on $t$. At $t=20-40^{\circ} \mathrm{C}$, the slope of the anodic polarization is $0.06 \mathrm{~V}$, but a limiting current is observed at higher $t$ values. At $t \leq 40^{\circ} \mathrm{C}$, the slope of cathodic polarization amounts to $0.12 \mathrm{~V}$. However, a limiting current is also observed at $t \geq 80^{\circ} \mathrm{C}$. In both cases, the onset of limiting currents with an increase in $t$ is a consequence of the presence of sludge on the metal surface and the abundant evolution of gaseous hydrogen that shields the surface. An increase in $t$ results in a consistent increase in cathodic and anodic currents, but, starting from $t=80^{\circ} \mathrm{C}$, the electrode reaction rates begin to grow much more slowly.

The above data differ significantly from the results of the study [111] according to which, based on 8-hour tests, the $k$ of St3 steel in $0.5-20 \% \mathrm{H}_{3} \mathrm{PO}_{4}$ are $\leq 17.7 \mathrm{~g} /\left(\mathrm{m}^{2} \cdot \mathrm{h}\right)$ at $t=100^{\circ} \mathrm{C}$ and $k \leq 46.4 \mathrm{~g} /\left(\mathrm{m}^{2} \cdot \mathrm{h}\right)$ at $t=200^{\circ} \mathrm{C}$. We believe that the data presented in this work are significantly underestimated as a consequence of extremely long corrosion tests and addition of distilled water (1/4 of the autoclave system volume) for suppressing the evaporation of the acid solution. Evaporation of this water inside the autoclave clearly led to the dilution of the corrosive medium acting on the metal. As a result, extremely low $k$ values were obtained for $\mathrm{St} 3$ steel.

A more complex corrosion behavior is observed for Kh18N10T chromium-nickel steel (content in mass percent, \%: $0.11 \mathrm{C} ; 9.66 \mathrm{Ni} ; 18.66 \mathrm{Cr} ; 0.57 \mathrm{Ti}$; remainder $\mathrm{Fe}$ ) in $1-10 \mathrm{M} \mathrm{H}_{3} \mathrm{PO}_{4}\left(100-150^{\circ} \mathrm{C}\right)$. E.V. Filimonov et al. [70,71] have shown that the chromium-nickel steel is in unstable passive state in this medium: a few similar samples present in exactly the same corrosive medium are destroyed at rates differing by more than an order of magnitude. Moreover, the maximum $k$ of the samples reach tens of $\mathrm{g} /\left(\mathrm{m}^{2} \cdot \mathrm{h}\right)$, 
while the minimum ones do not exceed $0.31 \mathrm{~g} /\left(\mathrm{m}^{2} \cdot \mathrm{h}\right)$. According to [111], chromiumnickel steels are more resistant to the action of phosphoric acid solutions. In fact, 06Kh23N28MDT steel (content in mass percent,\%: $0.06 \mathrm{C}$; 22-25 Cr; 26-29 Ni; up to 0.8 $\mathrm{Si}$; up to $0.8 \mathrm{Mn}$; up to $0.02 \mathrm{~S}$; up to $0.035 \mathrm{P}$; $2.5-3.5 \mathrm{Cu}$; 2.5-3.0 $\mathrm{Mo}$; $0.5-0.9 \mathrm{Ti}$; remainder $\mathrm{Fe}$ ) is most resistant to the action of $0.5-20 \% \mathrm{H}_{3} \mathrm{PO}_{4}$ : at $200^{\circ} \mathrm{C}$, its $k$ amounts to $0.005-0.661 \mathrm{~g} /\left(\mathrm{m}^{2} \cdot \mathrm{h}\right)$.

In recent years, concentrated phosphoric acid has been considered as an electrolyte for fuel cells operated at $t>100^{\circ} \mathrm{C}$ [112]. The electrochemical behavior of the following steels was studied in a search for electrode materials for such devices: $316 \mathrm{~L}$ (content in mass percent,\%: $0.03 \mathrm{C}$; $16-18 \mathrm{Cr} ; 10-14 \mathrm{Ni} ; 0.75 \mathrm{Si} ; 2.0 \mathrm{Mn}$; up to $0.030 \mathrm{~S}$; up to $0.045 \mathrm{P}$; 2.0-3.0 Mo; up to $0.10 \mathrm{~N}$; remainder $\mathrm{Fe}$ ), 317L (content in mass percent, \%: $0.03 \mathrm{C}$; 18-20 $\mathrm{Cr}$; $11-15 \mathrm{Ni}$; 0.75 Si; 2.0 Mn; up to $0.030 \mathrm{~S}$; up to $0.045 \mathrm{P}$; 3.0-4.0 Mo; up to 0.10 $\mathrm{N}$; remainder $\mathrm{Fe}$ ), 904L (content in mass percent, \%: $20 \mathrm{Cr} ; 25 \mathrm{Ni} ; 1.5 \mathrm{Mn} ; 1 \mathrm{Cu} ; 4.5 \mathrm{Mo}$; remainder $\mathrm{Fe})$ in $98 \% \mathrm{H}_{3} \mathrm{PO}_{4}\left(170^{\circ} \mathrm{C}\right)$. It has been shown that these steels are in passive state at potentials of operation of electrodes in fuel cells $(0.1$ and $0.7 \mathrm{~V})$.

\section{Organic acids}

The advantage of organic acids compared to mineral acids in the acid treatment of oil and gas bearing strata lies in their lower corrosivity toward the steel structures of field equipment and slower interaction with the minerals forming the strata. If the contact time between the acid and the well pipe is long or the temperature in the borehole is very high, organic acids can be used to reduce the corrosion loss of metals. It should be borne in mind that the dissolving capability of organic acids is smaller than that of mineral acids, which leads to a less efficient reaction between the acid and the minerals in the stratum. As a rule, two organic acids are used for acid treatment, namely, acetic and formic acids, more rarely citric acid. Formic and acetic acids are more expensive than $\mathrm{HCl}$, but they are often used in the treatment of strata at high temperatures. It is technologically important here that they act more slowly and more carefully on a carbonate rock than $\mathrm{HCl}$ that is extremely corrosive under these conditions, which creates undesired cracks in the rock [113-115].

The most comprehensive information on the high-temperature corrosion of steel in acetic acid was reported in [116], where data on the dissolution kinetics of steel 10 (content in mass percent,\%: $0.07-0.14 \mathrm{C}$; $0.17-0.37 \mathrm{Si}$; $0.35-0.65 \mathrm{Mn}$; up to $0.25 \mathrm{Ni}$; up to 0.25 $\mathrm{Cu}$; up to $0.15 \mathrm{Cr}$; up to $0.08 \mathrm{As}$; up to $0.035 \mathrm{P}$; up to $0.04 \mathrm{~S}$; remainder $\mathrm{Fe}$ ) in its solutions with $C=1-12 \mathrm{M}$ in the temperature range of $t=20-150^{\circ} \mathrm{C}$ were provided. At $t>100^{\circ} \mathrm{C}$, the acid becomes rather corrosive, and the $k$ of steel is $0.15-0.45 \mathrm{~kg} /\left(\mathrm{m}^{2} \cdot \mathrm{h}\right)$ (Figure 9). It was shown that with an increase in the acid temperature from 100 to $130^{\circ} \mathrm{C}$, its concentration at which the maximum corrosivity toward steel was observed shifted from 4 to $8 \mathrm{M}$. It is assumed that the observed effect results from changes in the structure of acetic acid solutions, which leads to a change in the mechanism of steel anodic dissolution. 


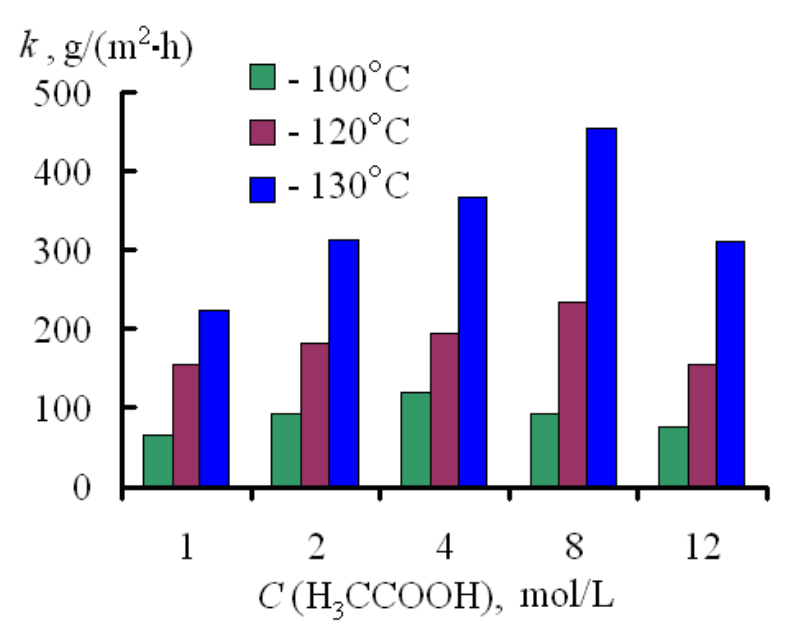

Figure 9. Corrosion rates of steel 10 in acetic acid solutions.

Studies performed later [117-121] provide information on the kinetics of dissolution of low carbon steels in acetic and formic acids at $t \leq 45^{\circ} \mathrm{C}$, although it is noted that in real situations, steel may contact these acids at high temperatures. More informative is the work [122] containing data on the corrosion of steel 20 in 2-6 $\mathrm{M}$ acetic and formic acids $\left(20-100^{\circ} \mathrm{C}\right)$. It has been shown (Table 3) that at $100^{\circ} \mathrm{C}$ the $k$ values of steel in acetic acid are $31.7-42.9 \mathrm{~g} /\left(\mathrm{m}^{2} \cdot \mathrm{h}\right)$, while in formic acid they are significantly higher and range within $109-226 \mathrm{~g} /\left(\mathrm{m}^{2} \cdot \mathrm{h}\right)$. In $4.0 \mathrm{M} \mathrm{H}_{3} \mathrm{CCOOH}$, the effective activation energy of the corrosion process amounts to $27 \mathrm{~kJ} / \mathrm{mol}$, which indicates that the reaction occurs in a mixed kinetics zone, close to diffusion control. In 4.0 M HCOOH, it is higher and amounts to $35 \mathrm{~kJ} / \mathrm{mol}$. In both acids $\left(100^{\circ} \mathrm{C}\right)$, steel 20 dissolves in the active region; the cathodic and anodic processes are characterized by limiting currents that are higher in $\mathrm{HCOOH}$. Hot solutions of citric acid are rather corrosive toward low-carbon St3 steel (Table 3): the $k$ values of steel at $95^{\circ} \mathrm{C}$ are within $57.4-106 \mathrm{~g}\left(\mathrm{~m}^{2} \cdot \mathrm{h}\right)$ [123].

Table 3. Corrosion rates* $\left(k, \mathrm{~g} /\left(\mathrm{m}^{2} \cdot \mathrm{h}\right)\right)$ of steel 20 in acetic acid solutions, steel 20 in formic acid solutions and steel St 3 in citric acid solutions. Test duration $-2 \mathrm{~h}$.

\begin{tabular}{ccccccccccc}
\hline & \multicolumn{3}{c}{ Acetic acid } & \multicolumn{3}{c}{ Formic acid } & \multicolumn{3}{c}{ Citric acid } \\
Temperature, ${ }^{\circ} \mathbf{C}$ & & & & & & & & \\
& $2.0 \mathrm{M}$ & $4.0 \mathrm{M}$ & $6.0 \mathrm{M}$ & $2.0 \mathrm{M}$ & $4.0 \mathrm{M}$ & $6.0 \mathrm{M}$ & $0.25 \mathrm{M}$ & $0.50 \mathrm{M}$ & $2.0 \mathrm{M}$ \\
\hline 20 & - & 4.0 & - & - & 9.7 & - & 1.93 & 1.95 & 2.01 \\
40 & - & 10.4 & - & - & 20.9 & - & 4.82 & 5.22 & 6.26 \\
60 & - & 15.6 & - & - & 41.9 & - & 15.1 & 17.6 & 22.5 \\
80 & - & 27.1 & - & - & 95.4 & - & 30.3 & 39.7 & 52.5 \\
95 & - & - & - & - & - & - & 57.4 & 66.6 & 106 \\
100 & 31.7 & 48.1 & 42.9 & 109 & 185 & 226 & - & - & - \\
\hline
\end{tabular}

$* k$ values are calculated from the loss of mass of metal samples. 


\section{Conclusions}

This review analyzes the areas of modern industry where problems of high-temperature acid corrosion of steel structures and equipment are encountered in practice. Analysis of literature data shows that this problem is most acute in the oil and gas industry where the acid stimulation of oil and gas bearing strata is performed at elevated temperatures at the mine bottom. Along with the well-known hydrochloric acid, acid stimulation of strata containing hydrocarbons is more and more often performed using $\mathrm{HF}$, less commonly $\mathrm{H}_{2} \mathrm{SO}_{4}, \mathrm{H}_{3} \mathrm{PO}_{4}, \mathrm{H}_{3} \mathrm{CCOOH}, \mathrm{HCOOH}$ and citric acid, in individual form or in mixtures. Despite the great importance of mixtures containing $\mathrm{HCl}$ and $\mathrm{HF}$ (mud acid) in acid stimulation operations, we failed to find data on the high-temperature corrosion of steels in this medium in the literature available to us. This is largely due to the high toxicity of HF and its extreme corrosivity toward various materials, especially in heated state.

A review of the equipment used in studies on high-temperature acid corrosion of metals is made. The technical specifics of experimental work and the difficulties that researchers may encounter in these studies are considered. The most comprehensive information about the process of high-temperature corrosion of steels can only be obtained by conducting studies in specialized autoclave equipment made of materials that can withstand the effects of extremely corrosive hot acids and the pressure growth due to the evaporation of components of a corrosive environment and the release of gaseous hydrogen. It should be possible to quickly heat and cool down the autoclave while accurately maintaining the temperature of the corrosive environment. It should be understood that the data on the corrosion rates of steels obtained during these studies, especially in non-inhibited solutions, are always underrated. The reasons for this lie in the high rates of corrosion processes that quickly reduce the concentrations of corrosive components in the corrosive environment, as well as in the screening of the surface with sludge that is formed with time. Electrochemical studies at elevated temperatures also involve certain difficulties. Sludge formation and release of gaseous hydrogen are enhanced upon cathodic and anodic polarization of the metal. These effects shield the surface of the steel electrode from the corrosive environment. As a result, both electrode reactions are characterized by a limiting current, which does not allow one to identify the true nature of the electrochemical reactions occurring on steel.

The experimental difficulties associated with the high-temperature corrosion of steels in acid solutions considerably limit the studies in this field, despite their practical importance. Estimation of corrosion losses of low carbon steels in $\mathrm{HCl}$ and $\mathrm{H}_{2} \mathrm{SO}_{4}$ solutions at $t>100^{\circ} \mathrm{C}$ indicates that they exceed $1 \mathrm{~kg} /\left(\mathrm{m}^{2} \cdot \mathrm{h}\right)$ and in some cases $10 \mathrm{~kg} /\left(\mathrm{m}^{2} \cdot \mathrm{h}\right)$, which poses a serious threat to the metal equipment. chromium-nickel steels are more resistant in these environments, but they also dissolve at great rates. Judging by the corrosion rate of low carbon steel in a solution of $\mathrm{H}_{3} \mathrm{PO}_{4}$ at $t=95^{\circ} \mathrm{C}$, the corrosion losses of the metal will exceed $1 \mathrm{~kg} /\left(\mathrm{m}^{2} \cdot \mathrm{h}\right)$ at higher temperatures.

The low corrosivity of organic acids toward low-carbon steels in acid treatment is largely a myth. Their corrosivity increases at temperatures close to $100^{\circ} \mathrm{C}$. Of course, it is 
lower than in mineral acids, but in many cases the $k$ of low-carbon steel exceeds $0.1 \mathrm{~kg} /\left(\mathrm{m}^{2} \cdot \mathrm{h}\right)$. Steels cannot be used in these environments without special protective measures. Metals in contact with hot both mineral and organic acids need to be protected.

The only acceptable way to protect a metal under these conditions is to use corrosion inhibitors, although this method involves certain difficulties. The majority of acid inhibitors stop protecting a metal at temperatures around $80^{\circ} \mathrm{C}$, and only some of them retain protective properties at higher temperatures. The second part of this review will examine these compounds and unique features of the mechanism of their protective action.

\section{Acknowledgments}

The study was carried out within the framework of the Program of Basic Scientific Research of the State Academies of Sciences for 2013-2020 on the subject "Development of the fundamental scientific basis of the protective effect of inhibitors of metal corrosion in gas and condensed media, nanocomposites, paint and conversion coatings" (state registration number AAAA-A18-118121090043-0).

\section{References}

1. ISO Standard 8044-1989.

2. B.B. Williams, J.L. Gidley and R.S. Schecter, Acidizing fundamentals, Monograph Series, 6, New York, Dallas, Society of Petroleum Engineers, 1979, 1-2.

3. P. Rae and G. Di Lullo, Matrix acid stimulation - a review of the State-Of-The-Art, Soc. Pet. Eng., SPE European Formation Damage Conference, 13-14 May, 2003, The Hague, Netherlands, SPE-82260-MS. doi: 10.2118/82260-MS

4. M.U. Shafiq and H.B. Mahmud, Sandstone matrix acidizing knowledge and future development, J. Pet. Explor. Prod. Technol., 2017, 7, no. 4, 1205-1216. doi: 10.1007/s13202-017-0314-6

5. S.S. Abdelmoneim and H.A. Nasr-El-Din, Determining the optimum HF Concentration for stimulation of high temperature sandstone formations, Soc. Pet. Eng., SPE European Formation Damage Conference and Exhibition, 3-5 June, 2015, Budapest, Hungary, SPE-174203-MS. doi: 10.2118/174203-MS

6. R.L. Thomas, H.A. Nasr-El-Din, S. Mehta, V. Hilab and J.D. Lynn, The impact of HCl to HF ratio on hydrated silica formation during the acidizing of a high temperature sandstone gas reservoir in Saudi Arabia, Soc. Pet. Eng., SPE Annual Technical Conference and Exhibition, 29 September-2 October 2002, San Antonio, Texas, SPE77370-MS. doi: 10.2118/77370-MS

7. R.S. Aboud, K.L. Smith, L. Forero Pachon and L.J. Kalfayan, Effective matrix acidizing in high-temperature environments, Soc. Pet. Eng., SPE Annual Technical Conference and Exhibition, 11-14 November, Anaheim, California, U.S.A., 2007, SPE-109818-MS. doi: $10.2118 / 109818-M S$ 
8. J. Rignol, T. Ounsakul, W. Kharrat, D. Fu, L.K. Teng, I. Lomovskaya and P. Boonjai, Improved Fluid Technology for Stimulation of Ultrahigh-Temperature Sandstone Formation, Soc. Pet. Eng., SPE International Symposium on Oilfield Chemistry, 13-15 April, 2015, The Woodlands, Texas, USA, SPE-173755-MS. doi: 10.2118/173755-MS

9. F. Yang, H.A. Nasr-El-Din and B.M. Al-Harbi, Acidizing Sandstone Reservoirs Using HF and Formic Acids, Soc. Pet. Eng., Damage Control, 15-17 February, Lafayette, Louisiana, USA, 2012, SPE-150899-MS. doi: 10.2118/150899-MS

10. L. Zhou and H.A. Nasr-El-Din, Acidizing Sandstone Formations Using a Sandstone Acid System For High Temperatures, Soc. Pet. Eng., SPE European Formation Damage Conference \& Exhibition, 5-7 June, Noordwijk, The Netherlands, 2013, SPE165084-MS. doi: $10.2118 / 165084-M S$

11. N. Pandya and S. Wadekar, A Novel Emulsified Acid System for Stimulation of Very High-Temperature Carbonate Reservoirs, Int. Petrol. Technol. Conf., 26-28 March, 2013, Beijing, China, IPTC-16452-MS. doi: 10.2523/IPTC-16452-MS

12.P. Kasza, M. Dziadkiewicz and M. Czupski, From Laboratory Research to Successful Practice: A Case Study of Carbonate Formation Emulsified Acid Treatments, Soc. Pet. Eng., SPE International Symposium and Exhibition on Formation Damage Control, 1517 February, Lafayette, Louisiana, USA, 2006, SPE-98261-MS. doi: 10.2118/98261MS

13. C. Growe, J. Masmonteil and R. Thomas, Trends in Matrix Acidizing, Oilfield Rev., 1992, no. 4, 24-40.

14. H.O. McLeod, Matrix Acidizing, Soc. Pet. Eng., 1984, 36, no. 12, 2055-2069. doi: 10.2118/13752-PA

15. G.R. Coulter and A.R. Jennings, A Contemporary Approach To Matrix Acidizing, Soc. Pet. Eng., SPE Annual Technical Conference and Exhibition, 5-8 October, 1997, San Antonio, Texas, SPE-38594-MS. doi: 10.2118/38594-MS

16. V.N. Glushchenko and M.A. Silin, Neftepromyslovaya khimiya. Vol. 4. Kislotnaya obrabotka skvazhyn (Oilfield chemistry. Vol. 4. Matrix acidizing), ed. I.T. Mishchenko, Intercontact Nauka, Moscow, 2010, 703 pp. (in Russian).

17. L.V. Hong and H.B. Mahmud, A preliminary screening and characterization of suitable acids for sandstone matrix acidizing technique: a comprehensive review, J. Pet. Explor. Prod. Technol., 2019, 9, 753-778. doi: 10.1007/s13202-018-0496-6

18. A.R. Hendrickson, R.L. Thomas and M.J. Economides, Ch. 13. Stimulation of Carbonate Reservoirs, Dev. Pet. Sci., 1992, 30, 589-625. doi: 10.1016/S03767361(09)70136-0

19. M.U. Shafiq and M.T. Shuker, Finding Suitable Acid for Acidizing of Low Permeable Sandstone Formation: A Research, Soc. Pet. Eng., SPE/PAPG Annual Technical Conference, 26-27 November, 2013, Islamabad, Pakistan, SPE-169641-MS. doi: $\underline{10.2118 / 169641-\mathrm{MS}}$ 
20. M.U. Shafiq, A. Kyaw and M.T. Shuker, A Comprehensive Research to Find Suitable Acid for Sandstone Acidizing, Adv. Mater. Res., 2013, 787, 274-280. doi: 10.4028/www.scientific.net/AMR.787.274

21. M.U. Shafiq, H.K.B. Mahmud and M.A. Hamid, Comparison of Buffer Effect of Different Acids During Sandstone Acidizing, IOP Conf. Ser.: Mater. Sci. Eng., 2015, 78, 012008. doi: 10.1088/1757-899X/78/1/012008

22. M.U. Shafiq and H.K.B. Mahmud, An Effective Acid Combination for Enhanced Properties and Corrosion Control of Acidizing Sandstone Formation, IOP Conf. Ser.: Mater. Sci. Eng., 2016, 121, 012002. doi: 10.1088/1757-899X/121/1/012002

23. M.U. Shafiq, H.K.B. Mahmud and R. Rezaee, New Acid Combination for a Successful Sandstone Acidizing, IOP Conf. Ser.: Mater. Sci. Eng., 2017, 206, 012010. doi: 10.1088/1757-899X/206/1/012010

24. L.V. Hong and H.B. Mahmud, A Comparative Study of Different Acids used for Sandstone Acid Stimulation: A Literature Review, IOP Conf. Ser.: Mater. Sci. Eng., 2017, 217, 012018. doi: 10.1088/1757-899X/217/1/012018

25.C. Xiong, F. Zhou, Y. Liu, X. Yang, X. Liu, Y. Shi, Y. Tan, F. Zhang, X. Ji, S. Qin, S. Huang and X. Wang, Application and Study of Acid Technique Using Novel Selective Emulsified Acid System, Soc. Pet. Eng., International Oil and Gas Conference and Exhibition in China, 8-10 June, Beijing, China, 2010, SPE-131216MS. doi: $10.2118 / 131216-\mathrm{MS}$

26. M. Buijse, P. De Boer, B. Breukel, M. Klos and G. Burgos, Organic Acids in Carbonate Acidizing, Soc. Petr. Engineers, SPE European Formation Damage Conference, 13-14 May, 2003, The Hague, Netherlands, SPE-82211-MS. doi: 10.2118/82211-MS

27. Ya.G. Avdeev, I.G. Gorichev and A.Yu. Luchkin, Effect of IFKhAN-92 inhibitor on scale removal during sulfuric acid pickling of steel, Int. J. Corros. Scale Inhib., 2012, 1, no. 1, 26-37. doi: 10.17675/2305-6894-2012-1-1-026-037

28. A.A. El-Meligi, S. Turgoose, A.A. Ismail and S.H. Sanad, Technical note effect of corrosion inhibitors on scale removal during pickling of mild steel, Brit. Corros. J., 2000, 35, no. 1, 75-77. doi: $10.1179 / 000705900101501029$

29. A. Agrawal and K.K. Sahu, An overview of the recovery of acid from spent acidic solutions from steel and electroplating industries, J. Hazard. Mater., 2009, 171, 61-75. doi: $10.1016 /$ j.jhazmat.2009.06.099

30. F. Rögener, Yu.A. Lednova, M.Yu. Andrianova and A.V. Lednov, Sustainable stainless steel - A review on acid regeneration systems for application in continuous pickling lines, Vestnik Magnitogorskogo gosudarstvennogo tekhnicheskogo universiteta im. G.I. Nosova (G.I. Nosov Vestnik Magnitogorsk State Technical University), 2019, 17, no. 2, 38-48. doi: 10.18503/1995-2732-2019-17-2-38-48 
31. S.V. Gorobets, M.I. Donchenko, O.Yu. Gorobets and I.Yu. Goiko, Effect of a Magnetic Field on the Etching of Steel in Nitric Acid Solutions, Russ. J. Phys. Chem., 2006, 80, no. 5, 791-794. doi: 10.1134/S0036024406050219

32.P. Fauvet, F. Balbaud, R. Robin, Q.-T. Tran, A. Mugnier and D. Espinoux, Corrosion mechanisms of austenitic stainless steels in nitric media used in reprocessing plants, J. Nucl. Mater., 2008, 375, no. 1, 52-64. doi: 10.1016/j.jnucmat.2007.10.017

33. S. Ningshen, U. Kamachi Mudali, G. Amarendra and B. Raj, Corrosion assessment of nitric acid grade austenitic stainless steels, Corr. Sci., 2009, 51, 322-329. doi: 10.1016/j.corsci.2008.09.038

34. S.A. Umoren and M.M. Solomon, Effect of halide ions on the corrosion inhibition efficiency of different organic species - A review, J. Ind. Eng. Chem., 2015, 21, 81100. 10.1016/j.jiec.2014.09.033

35. S.A. And El-Maksoud, The Effect of Organic Compounds on the Electrochemical Behaviour of Steel in Acidic Media. A review, Int. J. Electrochem. Sci., 2008, 3, 528555.

36. S.A. Umoren and M.M. Solomon, Recent Developments on the Use of Polymers as Corrosion Inhibitors - A Review, Open Mater. Sci. J., 2014, 8, 39-54.

37.C. Verma, E.E. Ebenso and M.A. Quraishi, Ionic liquids as green and sustainable corrosion inhibitors for metals and alloys: An overview, J. Mol. Liq., 2017, 233, $403-$ 414. doi: 10.1016/j.molliq.2017.02.111

38. M. Goyal, S. Kumar, I. Bahadur, C. Verma and E.E. Ebenso, Organic corrosion inhibitors for industrial cleaning of ferrous and nonferrous metals in acidic solutions: A review, $J$. Mol. Liq., 2018, 256, 565-573. doi: https://dx.doi.org/10.1016/j.molliq.2018.02.045

39. T.J. Harvey, F.C. Walsh and A.H. Nahlé, A review of inhibitors for the corrosion of transition metals in aqueous acids, J. Mol. Liq., 2018, 266, 160-175. doi: 10.1016/j.molliq.2018.06.014

40. L. Hamadi, S. Mansouri, K. Oulmi and A. Kareche, The use of amino acids as corrosion inhibitors for metals: A review, Egypt. J. Pet., 2018, 27, no. 4, 1157-1165. doi: 10.1016/j.ejpe.2018.04.004

41. S.H. Zaferani, M. Sharifi, D. Zaarei and M.R. Shishesaz, Application of eco-friendly products as corrosion inhibitors for metals in acid pickling processes - A review, $J$. Env. Chem. Eng., 2013, 1, no. 4, 652-657. doi: 10.1016/j.jece.2013.09.019

42. M.R. Vinutha and T.V. Venkatesha, Review on Mechanistic Action of Inhibitors on Steel Corrosion in Acidic Media, Port. Electrochim. Acta, 2016, 34, no. 3, 157-184. doi: $10.4152 /$ pea.201603157

43. G. Gece, Drugs: A review of promising novel corrosion inhibitors, Corros. Sci., 2011, 53, 3873-3898. doi: 10.1016/j.corsci.2011.08.006

44. A. Singh, E.E. Ebenso and M.A. Quraishi, Corrosion Inhibition of Carbon Steel in $\mathrm{HCl}$ Solution by Some Plant Extracts, Int. J. Corros., 2012, 2012, Article ID 897430, 20 pp. doi: $\underline{10.1155 / 2012 / 897430}$ 
45. A.A. Khadom and S.N. Farhan, Corrosion inhibition of steel in phosphoric acid, Corros. Rev., 2018, 36, no. 3, 267-280. doi: 10.1515/corrrev-2017-0104

46. M. Chigondo and F. Chigondo, Recent Natural Corrosion Inhibitors for Mild Steel: An Overview, J. Chem., 2016, 2016, Article ID 6208937, 7 pp. doi: $\underline{10.1155 / 2016 / 6208937}$

47. A. Peter, I.B. Obot and S.K. Sharma, Use of natural gums as green corrosion inhibitors: an overview, Int. J. Ind. Chem., 2015, 6, 153-164. doi: 10.1007/s40090-015-0040-1

48. Ch. Verma, D.K. Verma, E.E. Ebenso and M.A. Quraishi, Sulfur and phosphorus heteroatom-containing compounds as corrosion inhibitors: An overview, Heteroat. Chem., 2018, 29, no. 4, 20 pp. doi: $10.1002 /$ hc. 21437

49. R.K. Vagapov, Yu.I. Kuznetsov and A.V. Agafonkin, Ingibirovaniye korrozii metallov osnovaniyami Shiffa v rastvorakh mineral'nykh kislot (Inhibition of metals corrosion in solutions of mineral acids by Schiff bases), Korroz.: mater., zashch. (Corrosion: Materials, Protection), 2013, no. 4, 37-46 (in Russian)

50. K. Rasheeda, V.D.P. Alva, P.A. Krishnaprasad and S. Samshuddin, Pyrimidine derivatives as potential corrosion inhibitors for steel in acid medium - An overview, Int. J. Corros. Scale Inhib., 2018, 7, no. 1, 48-61. doi: 10.17675/2305-6894-2018-7-1-5

51.B.D.B. Tiu and R.C. Advincula, Polymeric corrosion inhibitors for the oil and gas industry: Design principles and mechanism, React. Funct. Polym., 2015, 95, 25-45. doi: $10.1016 /$ j.reactfunctpolym.2015.08.006

52. G. Schmitt, Application of Inhibitors for Acid Media, Br. Corros. J., 1984, 19, no. 4, $165-176$.

53. A. Singh and M.A. Quraishi, Acidizing Corrosion Inhibitors: A Review, J. Mater. Environ. Sci., 2015, 6, no. 1, 224-235.

54. M. Finšgar and J. Jackson, Application of corrosion inhibitors for steels in acidic media for the oil and gas industry: A review, Corros. Sci., 2014, 86, 17-41. doi: 10.1016/j.corsci.2014.04.044

55. Yu.I. Kuznetsov, New possibilities of metal corrosion inhibition by organic heterocyclic compounds, Int. J. Corros. Scale Inhib., 2012, 1, no. 1, 3-15. doi: 10.17675/2305-6894-2012-1-1-003-015

56. Yu.I. Kuznetsov, Progress in the science of corrosion inhibitors, Int. J. Corros. Scale Inhib., 2015, 4, no. 1, 15-34. doi: 10.17675/2305-6894-2015-4-1-015-034

57. Yu.I. Kuznetsov, A.A. Chirkunov and A.M. Semiletov, Progress in the inhibition of metal corrosion and the prospects of its use in the oil and gas industry, Int. J. Corros. Scale Inhib., 2019, 8, no. 4, 850-881. doi: 10.17675/2305-6894-2019-8-4-5

58. N.I. Podobaev and Ya.G. Avdeev, A Review of Acetylene Compounds as Inhibitors of Acid Corrosion of Iron, Prot. Met., 2004, 40, no. 1, 7-13. doi: 10.1023/B:PROM.0000013105.48781.86

59. Ya.G. Avdeev, Protection of Steel in Solutions of Mineral Acids Using $\alpha, \beta$-Unsaturated Aldehydes, Ketones, and Azomethines, Prot. Met. Phys. Chem. Surf., 2015, 51, no. 7, 1140-1148. doi: $10.1134 /$ S2070205115070023 
60. Ya.G. Avdeev and Yu.I. Kuznetsov, Physicochemical aspects of inhibition of acid corrosion of metals by unsaturated organic compounds, Russ. Chem. Rev., 2012, 81, no. 12, 1133-1145. doi: 10.1070/RC2012v081n12ABEH004292

61. Ya.G. Avdeev, Nitrogen-containing six-membered heterocyclic compounds as corrosion inhibitors for metals in solutions of mineral acids - A review, Int. J. Corros. Scale Inhib., 2018, 7, no. 4, 460-497. doi: 10.17675/2305-6894-2018-7-4-1

62. Ya.G. Avdeev, Protection of metals in phosphoric acid solutions by corrosion inhibitors. A review, Int. J. Corros. Scale Inhib., 2019, 8, no. 4, 760-798. doi: 10.17675/2305-6894-2019-8-4-1

63. I.B. Obot, I.B. Onyeachu, S.A. Umoren, M.A. Quraishi, A.A. Sorour, T. Chen, N. Aljeaban and Q. Wang, High temperature sweet corrosion and inhibition in the oil and gas industry: Progress, challenges and future perspectives, J. Pet. Sc. Eng., 2020, 185, 106469. doi: $10.1016 /$ j.petrol.2019.106469

64. S.A. Balezin, N.I. Podobayev and F.K. Kurbanov, Izucheniye skorosti rastvoreniya stali-3 v solyanoi kislote razlichnykh kontsentratsii $\mathrm{v}$ zavisimosti ot davleniya $\mathrm{i}$ temperatury (The study of the dissolution rate of steel-3 in hydrochloric acid of various concentrations depending on pressure and temperature), Zh. Prikl. Khim. (Russ. J. Appl. Chem.), 1964, 37, no. 11, 2523-2528 (in Russian).

65. V.V. Vasil'yev and N.I. Podobaev, Metodika provedeniya korrozionnykh ispytanii i elektrokhimicheskikh izmerenii pri vysokikh temperaturakh i davlenii (Methodology for conducting corrosion tests and electrochemical measurements at high temperatures and pressures), Zavodskaya laboratoriya (Factory laboratory), 1968, 34, no. 10, 12121213 (in Russian).

66. Ya.G. Avdeev, A.Yu. Luchkin, Yu.I. Kuznetsov, I.G. Gorichev and M.V. Tyurina, Zashchita nizkouglerodistoi stali $\mathrm{v}$ serno-kislykh rastvorakh ot vysokotemperaturnoi korrozii (do $200^{\circ} \mathrm{C}$ ) (Protection of low carbon steel in sulfuric acid solutions from high temperature corrosion (up to $200^{\circ} \mathrm{C}$ )), Korroz.: mater., zashch. (Corrosion: Materials, Protection), 2011, no. 8, 20-26 (in Russian).

67. Ya.G. Avdeev, A.Yu. Luchkin, Yu.I. Kuznetsov, I.G. Gorichev and M.V. Tyurina, Zashchita nizkouglerodistoi stali v solyanokislykh rastvorakh ot vysokotemperaturnoi korrozii (do $160^{\circ} \mathrm{C}$ ) (Protection of low carbon steel in hydrochloric acid solutions from high temperature corrosion (up to $160^{\circ} \mathrm{C}$ )), Korroz.: mater., zashch. (Corrosion: Materials, Protection), 2011, no. 10, 26-31 (in Russian).

68. Ya.G. Avdeev, D.S. Kuznetsov, M.V. Tyurina, S.V. Oleynik and M.A. Chekulaev, High-temperature inhibitors of stainless steel corrosion in sulfuric acid solutions, Int. J. Corros. Scale Inhib., 2017, 6, no. 1, 47-58. doi: 10.17675/2305-6894-2017-6-1-4

69. Ya.G. Avdeev, D.S. Kuznetsov, M.V. Tyurina, S.V. Oleynik and M.A. Chekulaev, High-temperature inhibitors of stainless steel corrosion in hydrochloric acid solutions, Int. J. Corros. Scale Inhib., 2017, 6, no. 2, 180-195. doi: 10.17675/2305-6894-2017-6$\underline{2-7}$ 
70.E.V. Filimonov, G.A. Ayuyan, A.I. Shcherbakov and T.A. Pisarenko, Korrozionnye i elektrokhimicheskie svoistva stali Kh18N10T v fosfornokislykh rastvorakh pri vysokoi temperature (Corrosion and electrochemical properties of steel X18H10T in phosphate solutions at high temperature), Zashchita metallov (Protection of metals), 1999, 35, no. 6, 656-659 (in Russian).

71.E.V. Filimonov, Vliyanie ionov okislitel'nogo tipa na ustoichivost' passivnogo sostoyaniya stali Kh18N10T v rastvorakh fosfornoi kisloty. Dissertatsiya kandidata khimicheskikh nauk (The effect of oxidizing ions on the stability of the passive state of X18H10T steel in phosphoric acid solutions. PhD Dissertation, Chemistry), Institute of Physical Chemistry, RAS, Moscow, 2004, 186 pp. (in Russian).

72. Ya.G. Avdeev and A.Yu. Luchkin, Effect of IFKhAN-92 inhibitor on electrode reactions and corrosion of mild steels in hydrochloric and sulfuric acid solutions, Int. J. Corros. Scale Inhib., 2013, 2, no. 1, 53-66. doi: 10.17675/2305-6894-2013-2-1-053-066

73. L.B. Kriksunov, Kinetika katodnogo vydeleniya vodoroda iz vodnykh rastvorov pri temperaturakh vyshe $100^{\circ} \mathrm{C}$. Dissertatsiya kandidata khimicheskikh nauk (Kinetics of cathodic hydrogen evolution from aqueous solutions at temperatures above $100^{\circ} \mathrm{C}$. PhD Dissertation, Chemistry), A.N. Frumkin Institute of Electrochemistry, USSR Academy of Sciences, Moscow, 1989, 127 pp. (in Russian).

74. F.K. Kurbanov and N.I. Podobaev, Issledovaniye vliyaniya davleniya na elektrodnyi potentsial $\mathrm{i}$ polyarizatsiyu stali $\mathrm{v}$ solyanoy kislote $\mathrm{v}$ prisutstvii ingibitorov (Investigation of the effect of pressure on the electrode potential and polarization of steel in hydrochloric acid in the presence of inhibitors), in Ingibitory korrozii metallov (Corrosion Inhibitors of Metals), ed. S.A. Balezin, Sudostroenie Publishing House, Moscow, 1965, pp. 95-99 (in Russian).

75. V.V. Vasil'yev and N.I. Podobaev, Metodika provedeniya korrozionnykh ispytanii i elektrokhimicheskikh izmerenii pri vysokikh temperaturakh i davlenii (Methodology for conducting corrosion tests and electrochemical measurements at high temperatures and pressure), in Ingibitory korrozii metallov (Corrosion Inhibitors of Metals), MGPI im. V.I. Lenina, Moscow, 1969, Issue 3, pp. 69-72 (in Russian).

76. N.I. Podobaev and V.V. Vasil'yev, K voprosu o mekhanizme deistviya ingibitorov kislotnoi korrozii pri vysokikh davleniyakh i temperaturakh (On the mechanism of action of acid corrosion inhibitors at high pressures and temperatures), in Ingibitory korrozii metallov (Corrosion Inhibitors of Metals), MGPI im. V.I. Lenina, Moscow, 1969, Issue 3, pp. 83-85 (in Russian).

77. V.V. Batrakov, V.P. Batrakov, L.N. Pivovarov and V.V. Sobol', Korroziya konstruktsionnykh materialov. Gazy i neorganicheskiye kisloty. V 2-kh knigakh. Kniga 2. Neorganicheskiye kisloty (Corrosion of structural materials. Gases and inorganic acids. In 2 books. Book 2. Inorganic acids), Intermet Inzhiniring, Moscow, 2000, 320 pp. (in Russian). 
78. N.D. Tomashov and G.P. Chernova, Teoriya korrozii $i$ korrozionnostoikie konstruktsionnye splavy (Corrosion theory and corrosion-resistant structural alloys), Moscow, Metallurgiya, 1993, 416 pp. (in Russian).

79. S.A. Balezin, F.K. Kurbanov and N.I. Podobaev, Issledovanie zashchitnogo deistviya ingibitorov korrozii stali $\mathrm{v}$ solyanoi kislote $\mathrm{v}$ zavisimosti ot temperatury, davleniya $\mathrm{i}$ kontsentratsii kisloty (Investigation of the protective effect of steel corrosion inhibitors in hydrochloric acid depending on temperature, pressure and acid concentration), Zashchita metallov (Protection of metals), 1965, 1, no. 3, 337-340 (in Russian).

80. N.I. Podobaev and V.V. Vasil'ev, O kinetike rastvoreniya stali v solyanoi kislote (On the kinetics of steel dissolution in hydrochloric acid), Zashchita metallov (Protection of metals), 1968, 4, no. 2, 223-227 (in Russian).

81. A.K. Iskhakov and F.K. Kurbanov, Ingibitory kislotnoi korrozii, effektivnye pri povyshennoi temperature (Acid corrosion inhibitors effective at elevated temperatures), Zashchita metallov (Protection of metals), 1983, 19, no. 6, 964-966 (in Russian)

82. E.S. Ivanov, Ingibitory korrozii metallov v kislykh sredakh (Metal Corrosion Inhibitors in Acid Media), Moscow, Metallurgiya, 1986, p. 121 (in Russian).

83. T. Kumar, S. Vishwanatham and Emranuzzaman, Study on corrosion control of N80 steel in acid medium using mixed organic inhibitors, Indian J. Chem. Technol., May 2008, 15, 221-227.

84. S. Vishwanatham and N. Haldar, Furfuryl alcohol as corrosion inhibitor for N80 steel in hydrochloric acid, Corros. Sci., 2008, 50, 2999-3004. doi: 10.1016/j.corsci.2008.08.005

85. M.A. Quraishi, N. Sardar and H. Ali, A Study of Some New Acidizing Inhibitors on Corrosion of N-80 Alloy in 15\% Boiling Hydrochloric Acid, Corrosion, 2002, 58, no. 4, 317-321.

86. M.A. Quraishi and D. Jamal, Dianils: New and Effective Corrosion Inhibitors for OilWell Steel (N-80) and Mild Steel in Boiling Hydrochloric Acid, Corrosion, 2000, 56, no. 2, 156-160. doi: $10.5006 / 1.3280531$

87. M.A. Quraishi and D. Jamal, Technical Note: CAHMT - A New and Eco-Friendly Acidizing Corrosion Inhibitor, Corrosion, 2000, 56, no. 10, 983-985. doi: $10.5006 / 1.3294388$

88. M.A. Quraishi, D. Jamal and M.T. Saeed, Fatty Acid Derivatives as Corrosion Inhibitors for Mild Steel and Oil-Well Tubular Steel in 15\% Boiling Hydrochloric Acid, JAOCS, 2000, 77, no. 3, 265-268.

89. M.A. Quraishi, S. Ahmad and S. Vishwanatham, Corrosion inhibitor of Mild Steel in Boiling Hydrochloric Acid by Some thiazole derivatives, Bull. Electrochem., 2002, 18, no. 9, 399-402.

90. D. Jayaperumal, Effects of alcohol-based inhibitors on corrosion of mild steel in hydrochloric acid, Mater. Chem. Phys., 2010, 119, 478-484. doi: 10.1016/j.matchemphys.2009.09.028 
91. A.R. Sathiya Priya, V.S. Muralidharan and A. Subramania, Development of Novel Acidizing Inhibitors for Carbon Steel Corrosion in 15\% Boiling Hydrochloric Acid, Corrosion, 2008, 64, no. 6, 541-552.

92.Z.M. Tsalikova, Sintez $i$ issledovaniye svoystv atsetilenovykh efirov. Avtoreferat dissernatsii kandidata khimicheskih nauk. (Synthesis and study of the properties of acetylene esters. Abstract of PhD dissertation, Chemistry), M. Azizbekov Azerbaijan Oil and Chemistry Institute, Baku, 1974, 31 pp. (in Russian).

93. S.F. Karayev, S.T. Kaziyeva and I.A. Shikhiyev, Vysokotemperaturnye ingibitory korrozii stali v rastvorakh solyanoi kisloty (High-temperature steel corrosion inhibitors in hydrochloric acid solutions), Korroziya $i$ zashchita $v$ neftegazovoy promyshlennosti (Corrosion and protection in the oil and gas industry), 1978, no. 2, 10-11 (in Russian).

94. N.I. Podobaev, V.E. Novikov and A.G. Voskresenskii, Izuchenie zashchitnogo deistviya nekotorykh proizvodnykh propargilovogo spirta i produktov ikh khimicheskikh prevrashchenii pri korrozii stali v solyanoi kislote (Study of the protective effect of certain derivatives of propargyl alcohol and products of their chemical transformations during corrosion of steel in hydrochloric acid), Zhurnal prikladnoy khimii (Russian Journal of Applied Chemistry), 1974, 47, no. 2, 370-374 (in Russian).

95. V.V. Vasil'ev, Issledovanie zashchitnogo deistviya vysokotemperaturnykh inhibitorov korrozii uglerodistoi stali $v$ solyanoi kislote. Avtoreferat dissertatsii kandidata khimicheskih nauk (Investigation of the protective effect of high-temperature corrosion inhibitors of carbon steel in hydrochloric acid. Abstract of PhD dissertation, Chemistry), MGPI im. V.I. Lenina, Moscow, 1974, 22 pp. (in Russian).

96. S.A. Balezin, N.I. Podobayev, A.G. Voskresenskii and V.V. Vasil'yev, O mekhanizme zashchitnogo deistviya atsetilenovykh soedinenii pri rastvorenii stali v solyanoi kislote (On the mechanism of the protective action of acetylene compounds upon dissolution of steel in hydrochloric acid), Trudy tret'ego mezhdunarodnogo kongressa po korrozii metallov (Proceedings of the Third International Congress on Metal Corrosion), Moscow, Mir, 1968, 2, 7-18 (in Russian).

97. A.K. Mishra, N. Ebrahimi, D.W. Shoesmith and P.E. Manning, Materials Selection for Use in Hydrochloric Acid, Corrosion 2016, 6-10 March, Vancouver, British Columbia, Canada, NACE International, 2016, NACE-2016-7680.

98. A. Mishra, D. Shoesmith and P. Manning, Materials Selection for Use in Concentrated Hydrochloric Acid, Corrosion, 2017, 73, no. 1, 68-76. doi: $\underline{10.5006 / 2193}$

99. Ya.G. Avdeev, D.S. Kuznetsov, M.V. Tyurina, A.Yu. Luchkin and M.A. Chekulaev, Protection of chromium-nickel steel in hydrochloric acid solution by a substituted triazole, Int. J. Corros. Scale Inhib., 2015, 4, no. 1, 1-14. doi: 10.17675/2305-68942015-4-1-001-014 
100. Z. Panossian, N. Lira de Almeida, R.M. Ferreira de Sousa, G. de Souza Pimenta and L.B.S. Marques, Corrosion of carbon steel pipes and tanks by concentrated sulfuric acid: A review, Corros. Sci., 2012, 58, 1-11. doi: 10.1016/j.corsci.2012.01.025

101. J.R. Rodda and M.B. Ives, Determination of Corrosion Rates in Hot, Concentrated Sulfuric Acid, Corrosion, 2003, 59, no. 4, 363-370. doi: 10.5006/1.3277569

102. I.G.A. Arwati, E.H. Majlan, W.R.W. Daud and L. Kee, Temperature Effects on Stainless Steel 316L Corrosion in the Environment of Sulphuric Acid $\left(\mathrm{H}_{2} \mathrm{SO}_{4}\right)$, IOP Conf. Series: Materials Science and Engineering, 2018, 343, 012016. doi: 10.1088/1757-899X/343/1/012016

103. Y. Wang, D. Wang and H. Zhang, Corrosion rate of carbon steel and aluminum alloy in sulfuric acid and hydrochloric acid solutions accelerated by microwave heating, AsiaPac. J. Chem. Eng., 2013, 8, 483-493. doi: 10.1002/apj.1685

104. Ya.G. Avdeev, P.A. Belinskii, Yu.I. Kuznetsov and O.O. Zel', High-Temperature Inhibitor of Steel Corrosion in Sulfuric Acid Solution, Prot. Met. Phys. Chem. Surf., 2010, 46, no. 7, 782-787. doi: 10.1134/S2070205110070087

105. Ya.G. Avdeev, D.S. Kuznetsov and S.V. Oleinik, Inhibitor Protection of Steels in Solutions of Sulfuric Acid under High-Temperature Corrosion (up to $200^{\circ} \mathrm{C}$ ), Prot. Met. Phys. Chem. Surf., 2018, 54, no. 7, 1305-1311. doi: 10.1134/S2070205118070067

106. Ya.G. Avdeev, D.S. Kuznetsov, M.V. Tyurina and M.A. Chekulaev, Protection of nickel-chromium steel in sulfuric acid solution by a substituted triazole, Int. J. Corros. Scale Inhib., 2015, 4, no. 2, 146-161. doi: 10.17675/2305-6894-2015-4-1-146-161

107. M. Benabdellah and B. Hammouti, Corrosion behaviour of steel in concentrated phosphoric acid solutions, Appl. Surf. Sci., 2005, 252, 1657-1661. doi: $\underline{\text { 10.1016/j.apsusc.2005.03.191 }}$

108. H. Li, Z. Jiang, H. Feng, S. Zhang, P. Han, W. Zhang, G. Li and G. Fan, Effect of Temperature on the Corrosion Behaviour of Super Austenitic Stainless Steel S32654 in Polluted Phosphoric Acid, Int. J. Electrochem. Sci., 2015, 10, 4832-4848.

109. Ya.G. Avdeev, M.V. Tyurina and Yu.I. Kuznetsov, Protection of low-carbon steel in phosphoric acid solutions by mixtures of a substituted triazole with sulfur-containing compounds, Int. J. Corros. Scale Inhib., 2014, 3, no. 4, 246-253. doi: 10.17675/23056894-2014-3-4-246-253

110. Ya.G. Avdeev and M.V. Tyurina, Vliyanie ingibitora IFKhAN-92 na elektrodnye reaktsii i korroziyu nizkouglerodistoi stali v rastvore fosfornoi kisloty (The influence of IFKhAN-92 inhibitor on the electrode reactions and corrosion of low carbon steel in a phosphoric acid solution), Korroz.: mater., zashch. (Corrosion: Materials, Protection), 2015, no. 6, 19-25 (in Russian).

111. M.Yu. Archakova, Yu.P. Kostikov and K.I. Tikhonov, Korrozionnaya stoikost' legirovannykh stalei $\mathrm{v}$ goryachikh rastvorakh ortofosfornoi kisloty (Corrosion resistance of alloyed steels in hot orthophosphoric acid solutions), Zhurnal prikladnoy khimii (Journal of Applied Chemistry), 1995, 68, no. 9, 1569-1571 (in Russian). 
112. H. Wang and J.A. Turner, Austenitic stainless steels in high temperature phosphoric acid, J. Power Sources, 2008, 180 803-807. doi: 10.1016/j.jpowsour.2008.02.086

113. B. Guo, X. Liu and X. Tan, Petroleum Production Engineering, Ch. 13, Acidizing, Gulf Professional Publishing, 2nd Edition, 2017, 367-387. doi: 10.1016/B978-0-12-809374$\underline{0.00013-1}$

114. F.F. Chang, H.A. Nasr-El-Din, T. Lindvig and X.W. Qui, Matrix Acidizing of Carbonate Reservoirs Using Organic Acids and Mixture of $\mathrm{HCl}$ and Organic Acids, Soc. Pet. Eng., SPE Annual Technical Conference and Exhibition, 21-24 September, Denver, Colorado, USA, 2008, SPE-116601-MS. doi: 10.2118/116601-MS

115. T. Huang, L. Ostensen and A.D. Hill, Carbonate Matrix Acidizing with Acetic Acid, in SPE International Symposium on Formation Damage Control, 23-24 February, Lafayette, Louisiana, Society of Petroleum Engineers, 2000, SPE-58715-MS. doi: $\underline{10.2118 / 58715-\mathrm{MS}}$

116. N.I. Podobaev and N.L. Khar'kovskaya, Issledovanie kinetiki rastvoreniya stali v uksusnoi kislote pri temperature do $150^{\circ} \mathrm{C}$ (Study of the kinetics of dissolution of steel in acetic acid at temperatures up to $150^{\circ} \mathrm{C}$ ), Uchenyye zapiski no. 340 (Scientific notes no. 340), MGPI im. V.I. Lenina, Moscow, 1971, 121-130 (in Russian).

117. M.M. Singh and A. Gupta, Corrosion Behavior of Mild Steel in Acetic Acid Solutions, Corrosion, 2000, 56, no. 4, 371-379. doi: $\underline{10.5006 / 1.3280540}$

118. M.M. Singh and A. Gupta, Corrosion behaviour of mild steel in formic acid solutions, Mater. Chem. Phys., 1996, 46, 15-22. doi: 10.1016/0254-0584(96)80124-6

119. S.K. Singh, A.K. Mukherjee and M.M. Singh, Kinetics of mild steel corrosion in aqueous formic acid solutions, Can. Metall. Q., 2011, 50, no. 2, 186-194. doi: $\underline{10.1179 / 000844311 X 12949307643515}$

120. S.K. Singh, A.K. Mukherjee and M.M. Singh, Corrosion behaviour of mild steel in aqueous acetic acid solutions containing different amounts of formic acid, Indian J. Chem. Technol., 2011, 18, no. 4, 291-300.

121. S.K. Singh and A.K. Mukherjee, Kinetics of Mild Steel Corrosion in Aqueous Acetic Acid Solutions, J. Mater. Sci. Technol., 2010, 26, no. 3, 264-269. doi: 10.1016/S10050302(10)60044-8

122. Ya.G. Avdeev, Yu.I. Kuznetsov and M.V. Tyurina, Ob ingibirovanii korrozii nizkouglerodistoi stali $\mathrm{v}$ goryachikh rastvorakh organicheskikh kislot (On Inhibition of Mild Steel Corrosion in Hot Organic Acid Solutions), Korroz.: mater., zashch. (Corrosion: Materials, Protection), 2012, no. 3, 24-28 (in Russian).

123. Ya. Avdeev, M. Tyurina, V. Rabinkov and A. Luchkin, Inhibitive Protection of LowCarbon Steel in Citric Acid Solutions, MATEC Web of Conferences, RSP 2017 - XXVI R-S-P Seminar 2017, Theoretical Foundation of Civil Engineering, 2017, 117, Article Number 00143. doi: $\underline{10.1051 / \text { matecconf } / 201711700143}$ 